\title{
PRESERVING MINORS' RIGHTS AFTER CASEY: THE "NEW BATTLEFIELD"* OF NEGLIGENCE AND STRICT LIABILITY STATUTES
}

\author{
PAMMELA S. QUINN**
}

\section{INTRODUCTION}

Every day in the United States, hundreds of minors ${ }^{1}$ walk into abortion clinics seeking to terminate unwanted pregnancies. ${ }^{2}$ Each of

* Okpalobi v. Foster, 981 F. Supp. 977, 986 (E.D. La. 1998), aff'd 190 F.3d 337 (5th Cir. 1999). Regarding the statute it was evaluating (which arguably imposed strict liability on abortion providers whose minor patients had not obtained required parental consent), the Okpalobi court stated: "The instant statute presents a new battlefield-that is unconstitutional regulation of abortion providers so as to directly strike at a woman's right of choice." Id.

** I would like to express my thanks to Kerry Quinn, who devoted so much time to helping me with this project. I cannot give enough credit for her help in developing, editing, and researching this Note.

1. In writing this Note, I wrestled with the problem of whether to use the term "girls" or "young women" to describe pregnant minors who must face and make the decision of whether to terminate their pregnancies. Unfortunately, no descriptive term recognizes the level of autonomy young women must have in making potentially life-altering decisions, without also denigrating the problem of young pregnant girls who do not, and in some cases cannot, understand the potential consequences of their decisions.

In the end, I decided to use the term "minor," which is admittedly not without problems. The gender-neutral often sounds awkward, precisely because only women and girls face the problem of making the ultimate decision regarding an unwanted pregnancy. Although the term may not capture all of the meaning I would like to suggest in referring to this group of pregnant teenagers, at least it does not imply anything that I do not wish to imply.

This problem - the lack of a word capturing the full reality of this particular situation-is highlighted in H.L. v. Matheson, 450 U.S. 398 (1981). In Matheson's majority opinion, which found a notification statute to be constitutionally permissible, Chief Justice Burger referred to the class represented by appellant as "unmarried minor girls." Id. at 405. Justice Marshall insisted on referring to this same group as "all minor women," as he argued that the notification provision was an unconstitutional restriction on their rights. Id. at 431 (emphasis deleted) (Marshall, J., dissenting).

2. In 1992, 960,180 teenagers in the United States became pregnant. See Stanley K. Henshaw, Teenage Abortion and Pregnancy Statistics by State, 1992, FAM. Plan. PERSP., May/June 1997 , at 115, 118 tbl.3. Of the teens who became pregnant in 1992, 36.9\% obtained an abortion. See id. at 117 tbl.1. This means that approximately 354,000 teenagers obtained abortions in the 
these minors has a constitutional right to an abortion. ${ }^{3}$ Yet, most of them will be turned away from the clinics they enter, unless they happen to bring with them a note from a parent. Permission slips, or some type of written proof that a parent is aware of his minor child's abortion decision, are mandated in most jurisdictions. ${ }^{4}$ Once placed on file at the clinic, these permission slips protect the abortion providers from liability. Or, at least until recently, abortion providers have assumed so.

Not long ago, sixteen-year-old Mukeshia Jackson entered an abortion clinic in Raleigh, North Carolina. ${ }^{5}$ Jackson brought with her

same year that Casey was decided, or an average of nearly one thousand per day.

3. See Planned Parenthood v. Danforth, 428 U.S. 52, 74 (1976) (holding unconstitutional a blanket parental consent requirement as a condition for an unmarried minor to obtain an abortion).

4. Forty states have on their books a statute requiring either parental consent or parental notice before a minor can obtain an abortion. See ALA. CODE § 26-21-3(a) (1992) (consent); Alaska Stat. § 18.16.020(1) (Michie 1998) (consent); ARIz. ReV. STAT. AnN. § 36-2152(A) (West Supp. 1998) (consent); ARK. CODE ANN. § 20-16-801 (Michie 1991) (notice); CAL. Health \& SAfety Code $§ 123450(a)$ (West 1996) (consent); Colo. Rev. Stat. AnN. § 1237.5-104(1) (West 1999) (notice); DEL. CoDE ANN. tit. 24, § 1783 (1997) (notice); Parental Notice of Abortion Act, 1999 Fla. Sess. Law Serv. 99-322, § 1 (West) (to be codified at FLA. STAT. ch. 390.01115) (notice); GA. CODE ANN. § 15-11-112 (a)(1) (1999) (notice); IDAHO CODE § 18609(6) (1997) (notice); 750 ILl. COMP. STAT. ANN. 70/15 (West 1999) (notice); IND. CODE ANN. § 16-34-2-4(a) (Michie 1993) (consent); Iowa CodE ANN. § 135L.3 (1) (West Supp. 1999) (notice); KAN. STAT. ANN. § 65-6705(a) (Supp. 1998) (notice); Ky. ReV. STAT. ANN. § 311.732(2)(a) (Banks-Baldwin 1997) (consent); LA. ReV. STAT. ANN. § 40:1299.35.5(A)(1) (West Supp. 1999) (consent); ME. Rev. StAT. AnN. tit. 22, § 1597-A(2)(A) (West 1992) (consent); MASS. ANN. LAws ch. 112, § 12 S (Law. Co-op. 1991) (consent); MiCH. COMP. LAws AnN. § 722.903 (West 1993) (consent); MinN. STAT. ANN. § 144.343(2) (West 1998) (notice); Miss. CodE ANN. § 41-41-53(1) (1993) (consent); Mo. ANN. STAT. § 188.028(1)(1) (West 1996) (consent); Mont. Code AnN. § 50-20-204 (1997) (notice); Neb. Rev. Stat. AnN. § 71-6902(1) (Michie 1998) (notice); Nev. ReV. STAT. AnN. § 442.255(1) (Michie 1996) (notice); N.M. StAT. ANN. § 30-5-1 (Michie 1994) (consent); N.C. GEN. STAT. § 90-21.7(a) (1997) (consent); N.D. Cent. Code § 14-02.1-03(1) (1997) (notice); Ohio Rev. Code AnN. § 2919.12(B)(1)(a) (Anderson 1998) (notice and consent); 18 PA. Cons. STAT. ANN. § 3206(a) (West Supp. 1999) (consent); R.I. GEN. LAWS § 23-4.7-6 (1996) (consent); S.C. CODE ANN. § 44-41-31(A)(1) (Law. Co-op. Supp. 1998) (consent); S.D. CoDIFIED LAws § 34-23A-7 (Michie Supp. 1999) (notice); TENN. CODE ANN. § 37-10-303(a) (1996) (consent); An Act Relating to Notification Before an Abortion May Be Performed on Certain Minors, 1999 Tex. Sess. Law Serv. 395 (West) (to be codified at TEX. FAM. CODE ANN. $\$ 33.002$ (West)) (notice); UTAH CODE ANN. $\S 76-7-304(2)$ (1995) (notice); VA. CODE ANN. § 16.1-241(V) (Michie 1999) (notice); W. VA. CODE § 16-2F-3(a) (1998) (notice); Wis. STAT. ANN. § 48.375(4)(1) (West 1997) (consent); WYO. STAT. ANN. § 35-6-118(a) (Michie 1999) (notice and consent).

Note that the Idaho and Utah statutes require that notice be provided to a minor's parents or legal guardian only "if possible." IDAHO CODE § 18-609(6) (1997); UTAH CODE ANN. § 76-7-304(2) (1995).

5. See Jackson ex rel. Robinson v. A Woman's Choice, Inc., 503 S.E.2d 422, 423 (N.C. Ct. App. 1998). 
a permission slip, consisting of a written note stating that she had her mother's permission to obtain an abortion, as was mandated under North Carolina law. ${ }^{6}$ The note was apparently signed by Jackson's mother, Alfreda Robinson.

When Jackson presented this note, both the clinic office manager and Dr. Washington, an abortion provider employed by the clinic, asked Jackson whether her mother had written and signed the note. After receiving verbal confirmation from Jackson that her mother had indeed written and signed it, Dr. Washington complied with legally required counseling requirements and obtained Jackson's written request and consent to perform the abortion procedure. At this point, only after he was certain that he had complied fully with each of the several legal requirements, Dr. Washington performed the abortion.

Unfortunately, Jackson had lied. The signature on the note she presented was not her mother's, but was forged by Jackson herself. Unluckily for Dr. Washington and the clinic, Jackson's parents found out about her abortion and decided to sue on their daughter's behalf for negligent infliction of emotional distress. ${ }^{7}$ The lawsuit contained no allegations of medical malpractice. In fact, Jackson and her parents agreed that the abortion had not resulted in any physical complications. Dr. Washington and the abortion clinic faced potential punitive and compensatory damages solely because they had not guessed or ascertained that the note Jackson brought with her had been forged. $^{8}$

The trial court dismissed Jackson's claim. ${ }^{9}$ On appeal, the Court of Appeals of North Carolina affirmed, holding that the North Carolina statute requiring written consent by a parent did not impose a strict liability duty on doctors to determine the validity of the signature..$^{10}$

However, the issue has yet to be resolved in most other states. ${ }^{11}$ Even in North Carolina, doctors and clinics cannot be sure they do

\footnotetext{
6. See N.C. Gen. STAT. § 90.21.7(a) (1997).

7. See Jackson, 503 S.E.2d at 423.

8. See id. at $423-24$.

9. See id. at 424 .

10. See id. at 426.

11. The only states in which the issue has been considered to date are South Dakota, Louisiana, and North Carolina. See Planned Parenthood, Sioux Falls Clinic v. Miller, 63 F.3d 1452, 1467-68 (8th Cir. 1995) (holding that the potential chilling effect of the challenged South Dakota statute caused it to be "an undue burden on a woman's right to choose whether to termi-
} 
not face future liability for failing to detect permission slip forgeries, since the North Carolina Supreme Court has not ruled on the issue. ${ }^{12}$ Moreover, even if the North Carolina Supreme Court eventually ratifies the appellate court's decision, the future is uncertain for Dr. Washington and his cohorts in the state of North Carolina. The legislature could amend the statute to explicitly create strict liability for abortion providers who perform abortions on minors without actual parental consent. Such a statute could also require that abortion providers police their minor patients.

The uncertainty doctors face as a result of parental consent statutes is problematic. Doctors who fear potential liability for failing to detect fraud would be well advised to refrain from performing abortions on all young women who appear as if they might be under the age of eighteen. Indeed, a doctor with considerably more patient documentation than the note presented by Mukeshia Jackson will never be absolutely sure of evading fraud. Even if a teenager is accompanied by an adult claiming to be a parent, the doctor cannot be

nate her pre-viability pregnancy"); Okpalobi v. Foster, 981 F. Supp. 977, 986 (E.D. La. 1998), aff'd 190 F.3d 337 (5th Cir. 1999) (holding that Louisiana's strict liability statute would "impose an undue burden on women seeking abortions in Louisiana" and invalidating the statute); Jackson, 503 S.E.2d at 425 (refusing to construe North Carolina's consent statute to impose strict liability on abortion providers, since such an interpretation "would raise a serious constitutional question").

A somewhat similar case from Tennessee resulted in summary judgment being affirmed in favor of a doctor who had performed an abortion on a minor two months before her eighteenth birthday. See McGlothlin v. Bristol Obstetrics, Gynecology \& Family Planning, Inc., No. 03A01-9706-CV-00236, 1998 WL 65459 (Tenn. Ct. App. Feb. 11, 1998). The doctor in McGlothlin did not provide the patient's parents with notice of the abortion, as required under Tennessee law. See id. at*2 (citing TenN. CoDE ANN. § 39-15-202(f) (1995)). However, because the statute did not contain a judicial bypass (as is constitutionally required, see infra notes 30-39), the court found it unconstitutional under both the federal and Tennessee constitutions, thereby exonerating the doctor's failure to comply with the statute. See id. at *4. Moreover, the court invoked the "mature minor" doctrine as alternate grounds for upholding summary judgment in favor of defendants. See id. at*5. This doctrine is a common law exception to the general requirement that parents must consent before their children can receive medical treatment. It allows a physician to perform medical treatment on minors who have the maturity to consent to the treatment without obtaining simultaneous consent from a parent. See, e.g., Cardwell v. Bechtol, 724 S.W.2d 739, 755 (Tenn. 1987) (adopting the "mature minor" exception in Tennessee). The existence of this doctrine is the reason that parental consent laws for abortion are especially onerous - before performing most medical procedures, doctors need only ascertain that the patient is mature (rather than actually 18 years old) in order to avoid liability for failing to obtain parental consent.

12. Nor will the North Carolina Supreme Court have occasion to consider the question until another suit analogous to Jackson's is brought. The North Carolina Supreme Court has denied review of the court of appeals decision. See Jackson ex rel. Robinson v. A Woman's Choice, Inc., 517 S.E.2d 896, 897 (N.C. 1998). 
certain that the adult is who he claims to be. Moreover, a prospective patient who represents herself to be over eighteen may be lying or carrying particularly convincing false identification.

However, while refusing to perform abortions on anyone who appears to be under eighteen would absolutely protect abortion providers from liability, such a solution raises troubling constitutional problems. Seemingly innocuous statutes, ostensibly passed with the purpose of protecting immature minors from making bad decisions, may become the de facto means of preventing minors from exercising their constitutional right to obtain pre-viability abortions.

In this Note, I argue that statutes that would hold abortion providers liable for failing to ensure that their minor patients have actually obtained legal consent are generally unconstitutional. The potential for liability would deter abortion providers from performing abortions on minors. This chilling effect would make it difficult or impossible for minors to obtain abortions, a result that is incompatible with a minor's constitutional right to choose this medical procedure.

Part I of this Note examines the existing state of the law regarding the right of a minor to obtain an abortion. Part II discusses why the "undue burden" standard articulated by the Supreme Court in Planned Parenthood v. Casey ${ }^{13}$ is the proper one for lower courts to apply in evaluating the constitutionality of statutes that regulate abortions performed on minors. In Part III, I argue that certain types of statutory and common law tort liability for abortion providers are unconstitutional. The potential for liability would create an unconstitutional chilling effect on the willingness of abortion providers to perform abortions on minors and those who appear to be minors. Statutes creating such a chilling effect, I conclude, work an undue burden on the right to obtain an abortion. Then, in Part IV, I examine and reject the counterargument that refusing to impose liability on abortion providers would effectively make consent statutes unenforceable.

\section{A MinOR's CONSTItUTIONAL Right OF CHOICE}

Although the disagreement over the constitutional right to abortion has generally been vigorous, and even violent, perhaps the various advocates on each side of the debate agree on one point. This

13. 505 U.S. 833 (1992). 
point may be only that the Supreme Court's current articulation of abortion rights jurisprudence emanates from a tremendously complex and confusing line of cases handed down over the past twentysix years. In this already difficult area, attempting to articulate the rights of minors is even harder.

The case law at least establishes that the Constitution gives women a fundamental right to choose abortion. ${ }^{14}$ Further, this right clearly extends to minors. ${ }^{15}$ The Supreme Court has also recognized that the states have certain compelling interests that justify some regulation of abortion generally ${ }^{16}$ and regulation of minors particularly. ${ }^{17}$ Nearly every state has a statute, or statutes, regulating a pregnant minor's right to choose an abortion. ${ }^{18}$ A brief summary of how the Supreme Court has dealt with abortion over the past twenty-six years provides helpful background to the analysis of current statutory efforts at regulation.

\section{A. Minors' Constitutional Right to an Abortion: Roe v. Wade and Planned Parenthood v. Danforth}

In 1973, the Supreme Court first announced that pregnant women have a constitutional right to choose abortion. That case, of course, was Roe v. Wade. ${ }^{19}$ The much-maligned decision ${ }^{20}$ articulated the now-infamous trimester framework.

The Roe opinion, authored for the Court by Justice Blackmun, discusses the right of privacy inherent in the Due Process Clause of

14. See Roe v. Wade, 410 U.S. 113, $152-54$ (1973); see also Planned Parenthood v. Casey, 505 U.S. 833, 845-53 (1992) (joint opinion of O'Connor, Kennedy, and Souter, JJ.).

15. See Planned Parenthood v. Danforth, 428 U.S. 52, 74 (1976).

16. See Casey, 505 U.S. at 846.

17. See Bellotti v. Baird, 443 U.S. 622, 633-34 (1979).

18. Forty states have either parental consent or parental notice requirements for minors who seek abortions. See supra note 4. Parental consent statutes require the written consent of a parent before a minor may obtain an abortion, while parental notice statutes require that actual or constructive notice be given to a parent before a doctor may perform an abortion on a minor. Each of the parental consent statutes has a judicial bypass procedure built in, as required by Bellotti. Most of the notice statutes contain an identical bypass procedure, although the federal courts are divided over whether Bellotti applies to notice statutes, and the Supreme Court has never explicitly ruled on the issue. For a more detailed discussion on this point, see infra Part I.C.2. Although the language of the statutes may vary slightly from jurisdiction to jurisdiction, the consent statutes are all very similar to one another, as are the notice statutes.

19. 410 U.S. 113 (1973).

20. See, e.g., John Hart Ely, The Wages of Crying Wolf: A Comment on Roe v. Wade, 82 YALE L.J. 920 (1973). Professor Ely's objections to Roe have been cited by innumerable scholars and judges over the past 26 years. 
the Fourteenth Amendment and concludes that this privacy right "is broad enough to encompass a woman's decision whether or not to terminate her pregnancy." ${ }^{21}$ However, Justice Blackmun cautions that the right to choose to terminate a pregnancy is not absolute; instead, because the state has an interest in "safeguarding health, in maintaining medical standards, and in protecting potential life," abortion may be regulated when these interests are implicated. ${ }^{22}$

Despite holding very generally that women have a constitutional right of choice, Roe expressly declined to consider whether an unmarried minor woman also could exercise this right. ${ }^{23}$ However, three years later, in Planned Parenthood v. Danforth, ${ }^{24}$ the Court declared unconstitutional a statute requiring parental consent before a minor could obtain an abortion. The Court, in an opinion also authored by Justice Blackmun, explained that the provision of the statute requiring parental consent was unconstitutional because it might prevent a minor from exercising her constitutional right simply because of a potentially arbitrary veto by a parent. ${ }^{25}$

In Danforth, Justice Blackmun establishes that minors also have a constitutional right to choose abortion. Indeed, he states firmly that "[c]onstitutional rights do not mature and come into being magically only when one attains the state-defined age of majority. Minors, as well as adults, are protected by the Constitution ...."26 Justice Blackmun makes clear that the state may not give absolute veto power over the minor's decision, even to the minor's parent or parents. ${ }^{27}$ This is so, Justice Blackmun asserts, because any interest the state might have in allowing parents to make their minor daughter's abortion decision does not outweigh the right of the minor to choose abortion, a right that is "protected by the Constitution." ${ }^{28}$ Justice Blackmun specifically rejects the notion that the state's interest in protecting the family unit and parental authority justifies parental veto power when that veto might be exercised arbitrarily. ${ }^{29}$

\footnotetext{
21. Roe, 410 U.S. at 153.

22. Id. at 154 .

23. See id. at 165 n.67.

24. 428 U.S. 52 (1976).

25. See id. at 72-75.

26. Id. at 74 .

27. See id.

28. Id.

29. See id.
} 
Abortion rights generally, and a minor's right to obtain an abortion in particular, are thus firmly established in Danforth. However, unlike Roe, which was decided by a fairly solid majority of seven, Danforth enjoyed a bare 5-4 majority. The closeness of the decision suggests the uneasiness that accompanies the Court's acknowledgement of a minor's right to terminate her pregnancy and anticipates the Court's subsequent decisions limiting the right to abortion.

\section{B. Limitations on the Constitutional Right to Abortion: Bellotti v. Baird and Planned Parenthood v. Casey}

Only three years after deciding Danforth, the Supreme Court began to place limitations on the constitutional right articulated in Roe and further explained in Danforth. In Bellotti v. Baird, ${ }^{30}$ the Court issued the first in a series of decisions clarifying that minors do not enjoy the same unchecked right to choose abortion as their adult counterparts.

Justice Powell wrote the plurality opinion in Bellotti, which has since been confirmed by a majority of the Supreme Court. ${ }^{31}$ In it, he examined a Massachusetts statute that limited a minor's ability to obtain an abortion by requiring the minor to obtain the consent of either a parent or a judge. To begin his analysis, Justice Powell confirms that there are "three reasons justifying the conclusion that the constitutional rights of children cannot be equated with those of adults: the peculiar vulnerability of children; their inability to make critical decisions in an informed, mature manner; and the importance of the parental role in child rearing., ${ }^{, 32}$

Justice Powell does indicate agreement with the essential holding of Danforth: "The need to preserve the constitutional right and the unique nature of the abortion decision, especially when made by

30. 443 U.S. 622 (1979).

31. See Ohio v. Akron Ctr. for Reprod. Health, 497 U.S. 502, 511-13 (1990).

32. Bellotti, 443 U.S. at 634 (declaring unconstitutional a statute requiring all unmarried minors seeking abortions to obtain either the consent of both parents or the approval of a superior court judge). Moreover, a state's interest in protecting the family unit and a parent's control of his child's upbringing are also values grounded in the Constitution, making them compelling. See Wisconsin v. Yoder, 406 U.S. 205, 231-33 (1972) (recognizing parents' interest in the religious upbringing and education of their children by striking down a state law compelling formal school attendance); Pierce v. Society of Sisters, 268 U.S. 510, 534-35 (1925) (noting that the Act challenged in the lawsuit "unreasonably interferes with the liberty of parents and guardians to direct the upbringing and education of children under their control"); Meyer v. Nebraska, 262 U.S. 390, 401-02 (1923) (supporting the right of parents to exercise some control over the education of their children). 
a minor, require a State to act with particular sensitivity when it legislates to foster parental involvement in this matter." ${ }^{33}$ Because of the aforementioned interest in protecting minors from their immaturity, however, Justice Powell concludes that some regulation of abortion is permissible. States can require parental consent, so long as the minor is provided with a judicial bypass option and can "go directly to a court without first consulting or notifying her parents." ${ }^{34}$ Justice Powell also makes clear that a minor's request must be approved by a court if the minor can prove either that she is "mature and well enough informed to make intelligently the abortion decision on her own" or "that an abortion ... would be in her best interests." 35 Thus, a judge has very limited discretion to deny a minor's request to have an abortion without parental consent. Only a minor whose best interests would not be served by an abortion and who is deemed immature may be refused a judicial bypass.

Bellotti has become the standard by which the lower federal courts measure the constitutionality of parental consent statutes. ${ }^{36}$ Statutes that do not contain a judicial bypass procedure exactly like the one outlined by Justice Powell are routinely invalidated. ${ }^{37}$ In theory, of course, lower court judges can always foreclose the minor's decision by declaring her to be immature. ${ }^{38}$ When this abuse of judi-

33. Bellotti, 443 U.S. at 642.

34. Id. at 647 .

35. Id. at 647-48. The Court recognizes that certain factors such as "education, employment skills, financial resources and emotional maturity" could make an unwanted pregnancy "exceptionally burdensome for a minor." To deny a minor the right to make the decision to terminate her pregnancy could, in some situations, result in "grave and indelible" consequences-a decision against her best interest. $I d$. at 642 .

36. See, e.g., Manning v. Hunt, 119 F.3d 254, 262-63 (4th Cir. 1997) (determining that a state law requiring parental consent for a minor's abortion satisfied the Bellotti criteria).

37. See, e.g., Causeway Med. Suite v. Ieyoub, 109 F.3d 1096, 1110 (5th Cir. 1997) (invalidating the modification of Louisiana's parental consent statute, which had increased judicial discretion to refuse bypasses of the consent statute).

38. See, e.g., LA. REV. STAT. ANN. § 40:1299.35.5 (West Supp. 1999) (authorizing courts to deny a waiver of parental notice upon determining that the minor is not mature and that the abortion is not in her best interest); ME. REV. STAT. ANN. tit. 22, §1597-A(6)(D) (West 1992) (same except authorizing a judicial waiver of parental consent); N.D. CENT. CODE \$14-02.103.1(5) (1997) (same); VA. CODE ANN. § 16.1-241 (Michie 1999) (same as the previously cited Louisiana statute); see also Patricia Donovan, Judging Teenagers: How Minors Fare When They Seek Court-Authorized Abortions, FAM. Plan. PersP., Nov./Dec. 1983, at 259, 259 (arguing that "although the judicial bypass laws and procedures ... may appear reasonable and workable on paper, in practice they constitute a serious, and in some cases insurmountable, barrier confronting minors who wish to obtain abortions"). The reaction of judges to the task of determining the maturity of minors has varied. One judge from Minnesota calls the expectation of assessing a minor's maturity in five minutes "almost absurd." Id. at 267. A judge from Massa- 
cial power occurs, it undoubtedly frustrates some minors who desire to abort without parental consent. However, such misappropriation of authority is often checked upon expedited appeal to appellate judges recognizing their constitutional duty. ${ }^{39}$

Bellotti, which allows states to regulate a minor's abortion decision in order to ensure that it is informed, foreshadowed the Court's decision in Casey. Casey was decided in 1992, after a number of split decisions that hinted the Court might overrule Roe. ${ }^{40}$ Casey generally affirms Roe, declaring that Roe was correct in its essential holding that women possess a constitutional right to choose abortion. ${ }^{41}$ However, the "undue burden" standard it articulates grants the state more power of regulation than did Roe, undermining the ability of adult women to exercise their right to choose with absolute impunity. ${ }^{42}$

The structure of the Casey decision is somewhat unusual, with a controlling “joint opinion," co-authored by Justices O'Connor, Kennedy, and Souter. ${ }^{43}$ Although not a majority opinion, Casey represents the minimum baseline against which abortion regulations must be measured, since Justices Blackmun and Stevens would have more severely limited the states' ability to regulate abortion than does the "undue burden" test articulated by the joint opinion writers. ${ }^{44}$

chusetts believes that she can learn enough in that period of time to make this judgment. See id. Another Massachusetts judge thinks the law "utterly preposterous" and charges that "the Court is a pure rubber stamp. All the law does is to harass kids. It sets up a barrier to abortion." Id. One judge, however, has noted that judges faced with bypass petitions have virtually no choice but to approve them. See Hiller B. Zobel, Judges and Abortion: The Judicial Question Becomes Political, Christian SCI. MONITOR, Oct. 17, 1984, at 16. Judge Zobel notes that judges who attempt to block a minor from obtaining a judicial bypass are always reversed. See id.

39. See, e.g., In the Matter of Doe, 485 S.E.2d 354, 356-357 (N.C. Ct. App. 1997).

40. See Webster v. Reproductive Health Servs., 492 U.S. 490 (1989) (validating the state's requirement of a viability test and recognizing the state's right to restrict the use of public employees and facilities for abortions when the mother's life is not in danger); Thornburgh $\mathrm{v}$. American College of Obstetricians \& Gynecologists, 476 U.S. 747, 771-72, 782-84, 813-14 (1986) (holding unconstitutional under Roe a statute that three of the four dissenters would have upheld under that standard).

41. See Planned Parenthood v. Casey, 505 U.S. 833, 846 (1992) (joint opinion of O'Connor, Kennedy, and Souter, JJ.).

42. See id.

43. Id. at 843-901.

44. See id. at 920 (Stevens, J., concurring in part and dissenting in part) (stating that he would apply the "undue burden" test to find the 24-hour waiting period unconstitutional); id. at 934 (Blackmun, J., concurring in part, concurring in the judgment in part, and dissenting in part) (saying that he would find the 24-hour waiting period unconstitutional under strict scrutiny analysis). Thus, the "undue burden" standard is controlling law since the Supreme Court has held that the most limited basis of a decision becomes law. See Marks v. United States, 430 
Before examining the Pennsylvania statute at issue in Casey, the joint opinion rejects the trimester framework of Roe and replaces it with a similar but different standard. The opinion concludes that drawing a line at viability is appropriate. ${ }^{45}$ Thus, "before [viability] the woman has a right to choose to terminate her pregnancy." ${ }^{46}$ However, a State may regulate abortion in order to "ensure that this choice [of abortion] is thoughtful and informed." ${ }^{47}$ The opinion then states the proper test of when a state regulation exceeds its constitutional limits: "where state regulation imposes an undue burden on a woman's ability to make this decision ... the power of the State" interferes unconstitutionally with the right to choose abortion. ${ }^{48}$ Undue burden is defined as "a state regulation [that] has the purpose or effect of placing a substantial obstacle in the path of a woman seeking an abortion of a nonviable fetus."

Such vague language makes the correct outcome of any particular case difficult to determine..$^{50}$ Considering the joint opinion's application of its own standard is therefore helpful. First, the opinion concludes that the twenty-four-hour waiting requirement mandated under Pennsylvania law does not constitute an undue burden, but admits that the question is a close one. ${ }^{51}$ Only because the party challenging the statute failed to include in the record that the waiting period constituted a "substantial" obstacle for the group most impeded by it does the wait not constitute an undue burden. ${ }^{52}$

Though not finding a wait of twenty-four hours so onerous as to constitute a "substantial obstacle," the joint opinion does hold that the Pennsylvania spousal notification law constituted an undue burden. ${ }^{53}$ Further, the reasoning behind the opinion writers' holding that

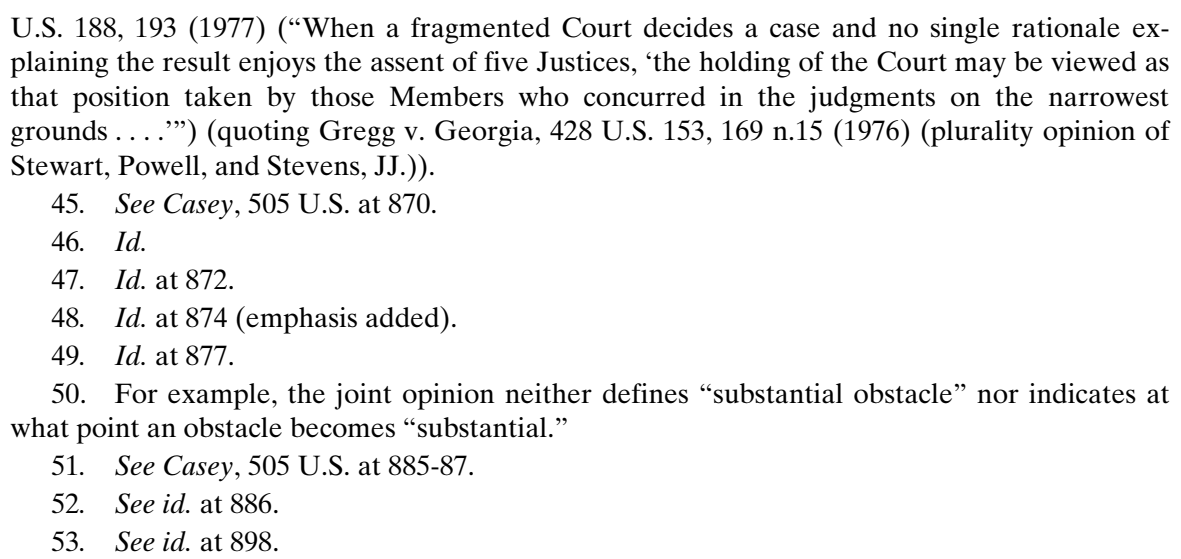


the notification provisions constituted an undue burden provides a way of evaluating other regulatory statutes. For example, the opinion notably rejects the contention that the statute is not an "undue burden," even though its application would hamper only one percent of women from obtaining elective abortions. ${ }^{54}$ Instead, the Court holds that the statutory notice requirement constitutes an undue burden because "[t]he [undue burden] analysis does not end with the one percent of women upon whom the statute operates; it begins there .... The proper focus of constitutional inquiry is the group for whom the law is a restriction, not the group for whom the law is irrelevant." ${ }^{55}$ Moreover, the opinion goes on to say that a statutory provision "is an undue burden" if, "in a large fraction of the cases in which [that provision] is relevant, it will operate as a substantial obstacle to a woman's choice to undergo an abortion."

\section{Current Abortion Regulations Aimed at Minors}

Since Bellotti and Casey, states have enacted many different types of statutes to regulate the abortion decision. The regulations most relevant to this Note are those having a potentially chilling effect on abortion providers performing abortions on minors. These and other types of regulations are outlined below, following a brief discussion of parental consent and parental notice requirements, the most prevalent types of abortion regulations.

1. Parental Consent Requirements. As mentioned above, parental consent statutes must, under Bellotti, meet certain requirements in order to be constitutional. ${ }^{57}$ Because the state has an interest in ensuring that minors are protected from making immature decisions, it may pass certain types of regulations that foster parental involvement in the minor's decisionmaking process. ${ }^{58}$ However, because the state's interest in assuring that the minor's decision is informed cannot absolutely overcome the minor's right of choice, the statutes regulating minors must not be so broad as to undercut the minor's right to choose. ${ }^{59}$ Thus, consent statutes may not require

\footnotetext{
54. See id. at 894.

55. Id.

56. Id. at 895.

57. See supra notes 35-39 and accompanying text.

58. See Bellotti v. Baird, 443 U.S. 622, 647 (1979) (plurality).

59. See id.
} 
consent by more than one parent. ${ }^{60}$ Moreover, because there may be no arbitrary veto of a minor's choice, parental consent statutes must contain a valid judicial bypass. ${ }^{61}$

In order to obtain a judicial bypass of a parental consent statute, the minor must file a petition with a court. ${ }^{62}$ Typically, upon the petition being filed, a guardian ad litem is appointed to represent the minor's interests before the court. ${ }^{63}$ Then, a state trial court judge will hold a hearing, in which she makes a determination of whether there is cause to grant the bypass - that is, whether the minor is mature or, if immature, whether the abortion is in the best interests of the minor. ${ }^{64}$ This hearing will normally take place in a timely manner, i.e., within a few days of the filing of the petition. ${ }^{65}$ If the minor's petition is denied by the judge, she may appeal the decision. Appeals are also expedited to assure that the minor is able to obtain an abortion in a timely manner should a bypass be granted. ${ }^{66}$

Twenty states currently have a parental consent requirement for minors wishing to obtain abortions. ${ }^{67}$ The statutes vary slightly from state to state ${ }^{68}$ but each contains a judicial bypass that is nearly always modeled after the Bellotti language. ${ }^{69}$ Indeed, statutes contain-

60. See Hodgson v. Minnesota, 497 U.S. 417, 457 (1990).

61. See Bellotti, 443 U.S. at 643-44.

62. One such example is South Carolina's law, which states that "[e]very minor has the right to petition the court for an order granting her the right to obtain an abortion without the [parental] consent [otherwise] required [by statute] ...." S.C. CODE ANN. § 44-41-32 (Law. Coop. Supp. 1998). This statute, typical of its kind, sets forth the procedure a minor would follow in petitioning the court for a waiver of the parental consent requirement.

63. See, e.g., id. § 44-41-32(3).

64. See, e.g., id. § 44-41-32(5).

65. See, e.g., id.

66. See, e.g., id. § 44-41-34(A).

67. See statutes cited supra note 4.

68. The statutes are all nearly identical and indeed often contain nearly identical language. Compare MicH. COMP. LAWs ANN. § 722.903(1) (West 1993) (“[A] person shall not perform an abortion on a minor without first obtaining the written consent of ... 1 of the parents or the legal guardian of the minor."), with ALA. CODE § 26-21-3(a) (1992) (“[N]o person shall perform an abortion upon an unemancipated minor unless he ... first obtains the written consent of either parent or the legal guardian of the minor.").

69. See, e.g., Мich. COMP. LAws ANN. § 722.904(4)(3) (West 1993). The Michigan statute provides:

The probate court shall grant a waiver of parental consent if it finds either of the following:

(a) The minor is sufficiently mature and well-enough informed to make the decision regarding abortion independently of her parents or legal guardian.

(b) The waiver would be in the best interests of the minor. 
ing language that does not conform to the Bellotti opinion's standard have usually been held unconstitutional. ${ }^{70}$

2. Parental Notice Requirements. Most states that do not have a parental consent statute have a parental notice requirement. ${ }^{71}$ Such statutes allow minors to make the abortion decision without parental approval, but require the abortion provider or the minor to notify a parent as a requirement of obtaining the abortion procedure. ${ }^{72}$ Because they pose less of a restriction than consent statutes on the minor's ability to choose abortion, notification statutes may require the involvement of both parents in order to avoid running afoul of the Constitution. ${ }^{73}$

Notification statutes can take several forms. Some states require the minor to present the abortion provider and clinic with a signed note stating that the minor has notified her parent (or parents ${ }^{74}$ ) of her decision to have the abortion. In other states, the minor faces a waiting period before having the abortion, during which time the parent is officially notified of the abortion by the abortion provider. ${ }^{75}$

As the Supreme Court has never explicitly ruled on the question, exactly what types of notification requirements would constitute an undue burden is not entirely clear. Indeed, there is no clear answer even to the question of whether a judicial bypass like the one outlined in Bellotti is required. ${ }^{76}$ The lower federal courts are somewhat

70. See, e.g., Causeway Med. Suite v. Ieyoub, 109 F.3d 1096, 1108-10 (5th Cir. 1997) (holding unconstitutional the judicial bypass procedure of Louisiana's parental consent statute, because its language, which provided that judges "may" grant a bypass, failed to require judges to grant the bypass, as is constitutionally required). But see Planned Parenthood v. Camblos, 155 F.3d 352, 383 (4th Cir. 1998) (en banc) (holding that the word "may" does not make the bypass procedure invalid, as the judges who will be granting bypasses should be presumed to exercise discretion only insofar as they will be acting constitutionally).

71. Currently, 21 states have a parental notice requirement. See statutes cited supra note 4.

72. See, e.g., DEL. CODE ANN. tit. 24, § 1783 (1997) (requiring notice be given to a minor's parent at least 24 hours prior to an abortion's being performed on the minor); MINN. STAT. ANN. § 144.343(2) (West 1998) (same with 48 hours' notice); S.D. CoDIFIED LAws § 34-23A-7 (Michie Supp. 1999) (same with 48 hours' notice).

73. See Hodgson v. Minnesota, 497 U.S. 417, 456-58 (1990).

74. See, e.g., DEL. CODE ANN. tit. 24, § 1783 (requiring notice of "one or both" parents before an abortion may be performed on a minor). The notification provision upheld in Hodgson required notification of both the minor's parents, with some exceptions. See Hodgson, 497 U.S. at 422 .

75. See, e.g., statutes cited supra note 72 .

76. See Lambert v. Wicklund, 520 U.S. 292, 295 (1997) (per curiam) (noting that the statute approved in a prior decision had a judicial bypass provision, which suggests that one might be constitutionally required); Jennifer C. Friedman, Note, Parental Notice in State Abortion 
split on the question. ${ }^{77}$ Although the issue has not come up often, at least one court has decided that a judicial bypass is require ${ }^{78}$ because the notification requirement, like a consent requirement, is permissible only when the state has a valid interest in mandating parental involvement in order to protect minors from making immature decisions. Bellotti makes clear that this state interest becomes invalid when the minor demonstrates either that she is capable of making a mature decision or that parental involvement is not in her best interest. $^{79}$

The Supreme Court has explicitly upheld judicial bypass procedures that allow a minor to bypass a notice requirement either because she is mature or because she can demonstrate that it would be in her best interest not to notify her parents about her abortion. ${ }^{80}$ However, the Court has yet to decide whether a notice statute must contain such a bypass, and some states have statutes that do not contain a procedure requiring judges to grant a bypass even if the maturity and "best interest" tests are met.

3. Other Statutes and Their Effects on Minors. States have also enacted other regulations. Courts have found several of these to violate the "undue burden" standard articulated by Casey. ${ }^{82}$ However, the various circuit courts do not always agree with one another as to what types of regulations constitute an undue burden. This disagreement is understandable, both because Casey contains no explicit definition of what amounts to a "substantial" obstacle, and because differences in interpreting facts often lead to differences of

Statutes: Filling the Gap in Constitutional Jurisprudence, 29 COLUM. HuM. RTS. L. REV. 437, 455-65 (1998) (arguing that the Bellotti judicial bypass requirement should also apply to notice statutes).

77. Compare Planned Parenthood, Sioux Falls Clinic v. Miller, 63 F.3d 1452, 1463 (8th Cir. 1995) (holding that a parental notification provision that did not include a bypass provision for mature minors was "unconstitutional on its face"), with Planned Parenthood v. Camblos, 155 F.3d 352, 374 (4th Cir. 1998) (finding that a notification statute that failed to contain a mandatory judicial bypass for mature minors was not facially invalid).

78. See Miller, 63 F.3d at 1463; see also Friedman, supra note 76, at 455-65 (arguing that the "undue burden" standard requires notice statutes to contain judicial bypass procedures).

79. See Bellotti v. Baird, 443 U.S. 622, 643-44 (1979) (plurality). But see Camblos, 155 F.3d at 381 (holding that a statute giving a judge discretion to deny a bypass to a minor is constitutional, despite the constitutional right announced in Bellotti).

80. See Lambert, 520 U.S. at 297-99.

81. See, e.g., VA. CodE ANN. § 16.1-241(V) (Michie 1999); Parental Notice of Abortion Act, § 1, 1999 Fla. Sess. Law Serv. 99-322, (West) (to be codified at FLA. STAT. Ch. 390.01115).

82. See infra notes $89-93$ and accompanying text. 
judicial opinion in close cases. ${ }^{83}$ The Supreme Court has yet to settle these disputes, as it has not given a precise definition of what constitutes a "substantial obstacle."

For the purposes of this Note, the most important types of regulations are statutes, passed in several jurisdictions, imposing criminal liability on doctors who perform abortions on minor patients who have not obtained valid parental consent. ${ }^{85}$ Such statutes, similar to the North Carolina statute at issue in Jackson, ${ }^{86}$ have yet to become the subject of litigation in many jurisdictions. ${ }^{87}$

Some of these statutes, like the one from North Carolina, do not elucidate what, if any, mens rea is required for an abortion provider to be held criminally liable. ${ }^{88}$ Statutes that expressly call for strict li-

83. Indeed, even the Justices who agreed that the "undue burden" standard was the appropriate test for constitutionality could not agree on whether Pennsylvania's 24-hour waiting requirement constituted an undue burden. Justices O'Connor, Kennedy, and Souter held that it was not. See Planned Parenthood v. Casey, 505 U.S. 833, 887 (1991) (joint opinion of O'Connor, Kennedy, and Souter, JJ.). Justice Stevens thought that it was. See id. at 921 (Stevens, J., concurring in part and dissenting in part). Justice Blackmun, applying strict scrutiny, also thought the waiting requirement was unconstitutional. See id. at 937 (Blackmun, J., concurring in part, concurring in the judgment in part, and dissenting in part).

84. See supra note 50 and accompanying text.

85. Other examples of abortion regulations include waiting periods, see, e.g., KAN. STAT. ANN. § 65-6709 (Supp. 1998), and the issuance of literature outlining alternatives to abortion, see, e.g., FLA. STAT. ch. 390.0111(3)(a)(2)(b) (1998).

86. See supra note 6.

87. Only Louisiana, South Dakota, and North Carolina statutes have been the subject of such litigation. See supra note 11. Other existing statutes might also prompt lawsuits. For example, in New Mexico it is a felony to use "any method or means whereby an untimely termination of ... [a] pregnancy is produced, or attempted to be produced, with the intent to destroy the fetus" where "the termination is not a justified medical termination." N.M. STAT. ANN. § 30-5-3 (emphasis added). Justified medical termination is defined as "the intentional ending of the pregnancy of a woman at the request of said woman or if said woman is under the age of eighteen years, then at the request of said woman and her then living parent or guardian, by a physician ...." Id. § 30-5-1 (emphasis added). Thus, based on this statutory definition, a physician performing an abortion on a minor who has not obtained parental consent will not be performing a "justified medical termination" and will be committing a felony. Because the New Mexico statute contains no judicial bypass, however, it has never been enforced by the New Mexico Attorney General. See N.M. Op. Att'y Gen. No. 90-19, at 5-7 (1990). Despite its current dormancy as a prosecutorial weapon, a private person might still invoke the criminal statute in a tort action.

88. For example, the above-mentioned New Mexico statute requires that a person have intent with respect to destroying the fetus. See N.M. STAT. ANN. § 30-5-3. However, it does not indicate that a person must intend to be acting in a manner that does not constitute a justified medical procedure. Indeed, with respect to the exception for a person performing a justified medical procedure, the statute does not even indicate that a violator must have knowledge or any other mental state. Similarly, the Louisiana statute invalidated by Okpalobi v. Foster had no explicit mental state requirement. See Okpalobi v. Foster, 981 F. Supp. 977, 979 (E.D. La. 
ability have been deemed unconstitutional by two courts because of their potential chilling effects. The Eighth Circuit, in Planned Parenthood v. Miller, ${ }^{89}$ struck a strict liability provision of a South Dakota statute because the statute's "chilling effect" "create[d] a substantial obstacle to a woman's right to have a pre-viability abortion ...." Similarly, a district court in Louisiana approved the reasoning of Miller in striking a portion of a Louisiana statute that appeared to impose strict liability on abortion providers. ${ }^{91}$

Moreover, a provision of one of these statutes that created a state tort action against abortion providers, but did not clearly state what mens rea would result in liability, was also found unconstitutional because of its chilling effect. ${ }^{92}$ In Jackson, the North Carolina Court of Appeals agreed that interpreting the North Carolina statute to impose strict liability would at least raise a serious constitutional question, and the court thus avoided the interpretation. ${ }^{93}$

As Part III will show, statutes akin to the North Carolina statute, but which explicitly create strict liability, should indeed be held unconstitutional under Casey. ${ }^{94}$ Before analyzing these statutes using the Casey test, however, this test must first be established as the proper one.

\section{WHY CASEY IS THE APPROPRIATE TEST FOR EVALUATING ABORTION REGULATIONS AFFECTING MINORS}

Though it might seem obvious that Casey is the proper basis for analyzing all statutes impinging the right to abortion, some disagreement on this question has prompted debate among the lower courts. ${ }^{95}$

1998), aff'd 190 F.3d 337 (5th Cir. 1999).

89. 63 F.3d 1452 (8th Cir. 1995).

90. Id. at 1465 (citation and internal quotation marks omitted).

91. See Okpalobi, 981 F. Supp. at 986.

92. See id. at 984 (holding that a statute that would have the effect of preventing abortion providers from performing abortions would "unconstitutionally prevent abortion providers from exercising their chosen profession" and that "[s]uch a reduction of abortion providers ... would also place an undue burden on a woman's right to choose").

93. See Jackson ex rel. Robinson v. A Woman's Choice, Inc., 503 S.E.2d 422, 425-26 (N.C. Ct. App. 1998) ("[E]ven if ... [the] construction [of strict liability] was reasonable, our own Supreme Court has instructed that where a statute is subject to two constructions, one of which would raise a serious constitutional question, the court should adopt the construction which avoids the constitutional problem.").

94. See infra Part III.

95. See Ruth Burdick, Note, The Casey Undue Burden Standard: Problems Predicted and Encountered, and the Split over the Salerno Test, 23 HASTINGS CONST. L.Q. 825 passim (1996). 
Before Casey was decided, the Court had adopted a general test for facial constitutional challenges in United States $v$. Salerno ${ }^{96}$ which $\mathrm{Ca}$ sey did not explicitly overrule. However, Casey implicitly replaced the Salerno test with the "undue burden" standard in the abortion context by its application of that standard. ${ }^{97}$ Thus, as discussed below, the abortion-specific Casey test, rather than the more general Salerno test, should be used to analyze the constitutionality of abortion regulations.

Moreover, Casey, rather than Bellotti, is the proper starting point in analyzing even those abortion statutes specifically regulating minors. Because Bellotti dealt specifically with the constitutionality of a parental consent statute, it is sometimes used by the lower courts as a starting point in analyzing all statutes regulating a minor's right to choose abortion. ${ }^{98}$ Although Bellotti still represents the standard courts should use to analyze judicial bypass provisions, Casey is the proper place to begin constitutional analysis of any abortion regulation. ${ }^{99}$ As I will discuss later, this is so because Bellotti can be read as an articulation of the "undue burden" standard in one specific context. ${ }^{100}$

\section{A. The Casey Test Versus the Salerno Test}

Although a majority of the Court in Casey affirmed the right to an abortion, one circuit — the Fifth-has refused to implement the

96. 481 U.S. 739 (1987). Prior to Casey, the Court applied the Salerno test in evaluating facial challenges to abortion regulations. See Rust v. Sullivan, 500 U.S. 173, 182-84 (1991); see also Webster v. Reproductive Health Servs., 492 U.S. 490, 524 (1989) (O'Connor, J., concurring).

97. Casey states that a statute is unconstitutional if it operates as a substantial obstacle "in a large fraction of the cases in which [it] is relevant." Planned Parenthood v. Casey, 505 U.S. 833, 895 (1992) (joint opinion of O'Connor, Kennedy, and Souter, JJ.). If the general test for facial challenges established in Salerno had been the appropriate test, the Court would have had to hold that a statute is invalid only if "no set of circumstances exists under which [it] would be valid." Salerno, 481 U.S. at 745.

98. See, e.g., Wicklund v. Salvagni, 93 F.3d 567, 571-72 (9th Cir. 1996) (evaluating a parental notification requirement under Bellotti), rev'd sub. nom Lambert v. Wicklund, 520 U.S. 292, 294-97 (1997) (per curiam).

99. Indeed, at least one court has even used the Casey "undue burden" standard to evaluate a parental consent provision exactly like the one at issue in Bellotti itself. See Planned Parenthood v. Lawall, 180 F.3d 1022, 1025-27 (9th Cir. 1999) (holding that Casey, rather than Salerno, is the proper test to use in evaluating the facial constitutionality of abortion regulations and applying that standard to Arizona's parental consent statute).

100. See infra Part II.B. 
"undue burden" test it set forth. ${ }^{101}$ Judges refusing to use the Casey test employ instead the test set forth in Salerno, a test that makes statutes much harder to invalidate.

In Salerno, the Supreme Court refused to find that the Bail Reform Act, which authorized pretrial detention on the basis of future dangerousness, violated the Eight Amendment. ${ }^{102}$ In so holding, the Court stated a very strict test for facial constitutional challenges: "A facial challenge to a legislative Act is, of course, the most difficult challenge to mount successfully, since the challenger must establish that no set of circumstances exists under which the Act would be valid. $" 103$

Even the Salerno Court acknowledges exceptions to this general rule, however. In fact, the next sentence of the opinion notes that a different test applies in First Amendment analysis. ${ }^{104}$ Furthermore, after Casey, Salerno no longer applies in the abortion context either. ${ }^{105}$ Chief Justice Rehnquist points out, in dissenting to Casey's

101. See Barnes v. Moore, 970 F.2d 12, 14 \& n.2 (5th Cir. 1992) (per curiam) (applying the Salerno "no circumstances" test and citing only to Chief Justice Rehnquist's dissent in Casey as support for its holding); see also Manning v. Hunt, 119 F.3d 254, 260, 268 n.4 (4th Cir. 1997) (noting that "since Roe, no one standard of review has secured a solid majority of the Court," even while refusing to hold explicitly that Salerno survives Casey in the abortion context).

However, the prevailing view among the circuits that have considered the question is that Casey is the proper standard to use, and most facial challenges to statutes regulating abortion are evaluated under the "undue burden" standard. See, e.g., Lawall, 180 F.3d at 1025-27; Women's Med. Prof'l Corp. v. Voinovich, 130 F.3d 187, 195-96 (6th Cir. 1997), cert. denied, 118 S. Ct. 1347 (1998); Jane L. v. Bangerter, 102 F.3d 1112, 1116 (10th Cir. 1996), cert. denied, 520 U.S. 1274 (1997); Planned Parenthood, Sioux Falls Clinic v. Miller, 63 F.3d 1452, 1456-58 (8th Cir. 1995), cert. denied, 517 U.S. 1174 (1996); Casey v. Planned Parenthood, 14 F.3d 848, 863 n.21 (3d Cir. 1994), stay denied, 510 U.S. 1309 (1994); see also Michael C. Dorf, Facial Challenges to State and Federal Statutes, 46 STAN. L. REV. 235, 238 (1994) (arguing that the Salerno "test" is merely dicta that should not be followed because it inaccurately states how the Supreme Court has historically approached facial challenges to statutes); $c f$. Causeway Med. Suite v. Ieyoub, 109 F.3d 1096, 1104 n.6 (5th Cir. 1997) (recognizing explicitly that Barnes's refusal to supplant the Salerno test with Casey is questionable, but refusing to address the issue of whether Barnes's holding was wrong when it could decide Ieyoub without having to consider the question).

102. See Salerno, 481 U.S. at 741.

103. Id. at 745 (emphasis added).

104. See id. ("[W]e have not recognized an 'overbreadth' doctrine outside the limited context of the First Amendment.").

105. See Planned Parenthood v. Casey, 505 U.S. 833, 874, 876 (1992) (joint opinion of O'Connor, Kennedy, and Souter, JJ.) (endorsing "undue burden" as the proper test, rather than the "no circumstances" Salerno test); see also City of Chicago v. Morales, 119 S. Ct. 1849, 1858 n.22 (1999) (emphasizing that the Salerno "no circumstances" test "has never been the decisive factor in any decision of this Court, including Salerno itself"); Dorf, supra note 101, at 272 (arguing that the Salerno test has no historical basis in Supreme Court precedent and that 
announcement of the "undue burden" standard, that the Pennsylvania notification statute held unconstitutional by a majority of the Court would have been upheld under Salerno's strict "no circumstances" test. ${ }^{106}$

Had Salerno been the proper test, the Court would have had to uphold the spousal notification requirement as facially valid. The $\mathrm{Ca}$ sey Court refused to do so. Instead, Casey clearly articulates the appropriate standard for evaluating statutes that might restrict a woman's right to choose abortion. The test the Casey Court sets out while analyzing the spousal notification provision is whether "in a large fraction of the cases in which [the provision] is relevant, it will operate as a substantial obstacle to a woman's choice to undergo an abortion." ${ }^{107}$ The Casey joint opinion explicitly acknowledges that the unconstitutional spousal notification provision of the Pennsylvania statute was an obstacle not only in some circumstances, but in most. ${ }^{108}$

Thus, the proper test for facial challenges to abortion statutes shifts the focus to the opposite extreme of Salerno. Unlike Salerno, in which a challenger had to prove a negative, showing "no set of circumstances" in which the restriction would be unconstitutional, under Casey, a successful challenger of an abortion statute need only look to the group, possibly very small, "for whom the law is a restriction, not the group for whom the law is irrelevant." group, only a "large fraction" need face a substantial obstacle for the statute to be facially unconstitutional. ${ }^{110}$ Thus, an abortion provision, like the spousal notification provision in Casey, may be facially invalid in cases where it would effect an unconstitutional infringement less than one percent of the time.

Despite the fact that Casey clearly did not use the Salerno standard, the Fifth Circuit continued to use this general test to evaluate facial challenges to abortion statutes. ${ }^{111}$ In one 1992 case, plaintiffs attempted a facial constitutional challenge to a Mississippi statute that

\footnotetext{
facial challenges to abortion statutes have often been held to a much more lenient test).

106. See Casey, 505 U.S. at $972-73$ (Rehnquist, C.J., concurring in part and dissenting in part) (asserting that Salerno's "no circumstances" test should have led to a different result).

107. Id. at 895 .

108. See id. at 894 .

109. Id.

110. See id. at 895 .

111. See Barnes v. Moore, 970 F.2d 12, 14 (5th Cir. 1992) (per curiam); see also Causeway Med. Suite v. Ieyoub, 109 F.3d 1096, 1104 n.6 (5th Cir. 1997) (refusing to overrule Barnes's use of the Salerno test rather than the Casey standard in the abortion context).
} 
mandated physician disclosure of all possible risks to abortion patients and a twenty-four-hour waiting period between such disclosure and the abortion itself. Interestingly, the court found the statute facially constitutional "[p]ursuant to Planned Parenthood of Southeastern Pennsylvania v. Casey ...."112 Yet, instead of evaluating the statute under the Casey undue burden standard, the opinion stated that "[b]ecause the plaintiffs are challenging the facial validity of the Mississippi Act, they must "establish that no set of circumstances exists under which the Act would be valid." "'113 Indeed, though purporting to find the Act unconstitutional under Casey, the opinion actually attributes its constitutional test to Salerno and to Chief Justice Rehnquist's dissent in Casey. ${ }^{114}$ Only in a footnote does the court acknowledge that Casey itself applied a different standard: "The Casey joint opinion may have applied a somewhat different standard in striking down the spousal notification provision of the Pennsylvania Act .... Nevertheless, we do not interpret Casey as having overruled [Salerno] ...."115

Because the Salerno test is inconsistent with Casey, other circuits have not followed the Fifth. ${ }^{116}$ Indeed, one commentator has noted that after Barnes, "the arguments ... support[ing]... the position that Casey overruled Salerno in facial challenges of state abortion regulation ... [became] more elaborate and persuasive."117 Indeed, the arguments of Barnes and other courts in favor of Salerno "ring[] flat and unconvincing." 118 Even the Fifth Circuit has subsequently indicated that Barnes's use of the Salerno test was very likely wrong. ${ }^{19}$ However, courts in the Fifth Circuit have continued to adhere to

112. Barnes, 970 F.2d at 13.

113. Id. at 14 (quoting United States v. Salerno, 481 U.S. 739, 745 (1987) and citing Casey, 505 U.S. at 973 (Rehnquist, C.J., dissenting)).

114. See id.

115. Id. at 14 n.2. (citations omitted).

116. See, e.g., Casey v. Planned Parenthood, 14 F.3d 848, 863 n.21 (3d Cir. 1994) (acknowledging that the Supreme Court opinion in Casey provides a new standard for facial challenges to abortion regulations), stay denied, 510 U.S. 1309 (1994); see also Planned Parenthood, Sioux Falls Clinic v. Miller, 63 F.3d 1452, 1458 (8th Cir. 1995) (same), cert denied, 517 U.S. 1174 (1996).

117. Burdick, supra note 95, at 875 .

118. Id.

119. See Causeway Med. Suite v. Ieyoub, 109 F.3d 1096, 1104 n.6 (5th Cir. 1997) (acknowledging Justice Stevens's doubt that, "given intervening statements by Members of [the Supreme] Court, ... subsequent Fifth Circuit panels would follow Barnes' application of the 'no circumstance' test ....") (quoting Janklow v. Planned Parenthood, Sioux Falls Clinic, 517 U.S. 1174, 1176 n.2 (1996) (Stevens, J., mem. respecting denial of certiorari)). 
Salerno-at least in theory. ${ }^{120}$ The Casey Court's failure explicitly to reject the Salerno framework in the abortion context has thus allowed some lower courts to uphold abortion regulations that would be unconstitutional under the proper standard, without forcing those courts to challenge directly the Supreme Court's abortion jurisprudence. ${ }^{121}$

Because of Barnes, several members of the Court have gone out of their way to confirm that Casey, rather than Salerno, is the proper test for facial challenges to abortion statutes. For example, Justice O'Connor has specifically stated that Casey provides the proper test for determining facial constitutionality:

In striking down Pennsylvania's spousal-notice provision [in Casey], we did not require petitioners to show that the provision would be invalid in all circumstances. Rather, we made clear that a law restricting abortions constitutes an undue burden... if, "in a large fraction of the cases in which [the law] is relevant, it will operate as a substantial obstacle to a woman's choice to undergo an abortion." 122

Justice Stevens has also stated that the Salerno test is an improper standard in the abortion area, as well as an improper standard generally: "[T]he dicta in Salerno "does not accurately characterize the standard for deciding facial challenges....' For [this reason], Salerno's rigid and unwise dictum has been properly ignored in sub-

120. Not all district courts in the Fifth Circuit have agreed with Barnes. See, e.g., Okpalobi v. Foster, 981 F. Supp. 977, 981 (E.D. La. 1998), aff'd 190 F.3d 337 (5th Cir. 1999) (noting the possible misapplication of the Salerno standard after Casey); Causeway Med. Suite v. Ieyoub, 905 F. Supp. 360, 363 n.2 (E.D. La. 1995) (same). Moreover, most of the district court decisions applying the Casey test have been affirmed by the Fifth Circuit, even though it purported to do so on different grounds. See, e.g., Ieyoub, 109 F.3d at 1104.

121. Arguably the Barnes court was craftily refusing to follow Supreme Court precedent by claiming to invalidate the Mississippi Act under Casey, while at the same time refusing to apply its "undue burden" standard. Indeed, it is hard to believe that the court claims to be following Casey when it cites only to a dissenting opinion in the case and makes clear in a footnote that it will not interpret Casey to be saying what it actually says. See Barnes v. Moore, 970 F.2d 12, 14 n.2 (5th Cir. 1992) (per curiam) ("The Casey joint opinion may have applied a somewhat different standard [than this opinion is applying] .... Nevertheless, we do not interpret Casey as having overruled, sub silentio, longstanding Supreme Court precedent governing challenges to the facial constitutionality of statutes.").

122. Fargo Women's Health Org. v. Schafer, 507 U.S. 1013, 1014 (1993) (O'Connor, J., joined by Souter, J., concurring) (quoting Planned Parenthood v. Casey, 505 U.S. 833, 895 (1992) (joint opinion of O'Connor, Kennedy, and Souter, JJ.)). But see Ada v. Guam Soc'y of Obstetricians \& Gynecologists, 506 U.S. 1011, 1012-13 (1992) (Scalia, J., joined by Rehnquist, C.J., and White, J., dissenting from the denial of certiorari because the lower federal court had applied Casey rather than Salerno in holding an abortion statute unconstitutional on its face). 
sequent cases even outside the abortion context." ${ }^{123}$ Moreover, in a very recent opinion for the Court, Justice Stevens again rejected the Salerno test, stating that "[t]o the extent we have consistently articulated a clear standard for facial challenges, it is not the Salerno formulation, which has never been the decisive factor in any decision of this Court, including Salerno itself . . .."124

The fact that Salerno was not explicitly overruled in Caseywhich is perhaps the only argument in favor of using Salerno to analyze abortion statutes ${ }^{125}$ - does not overcome the fact that the "undue burden" test did in fact replace the "no circumstances" standard in Casey itself, which remains controlling precedent. Not only did the Casey test represent a baseline point of agreement by the Court at the time it was articulated, ${ }^{126}$ it has also been confirmed as the appropriate test in subsequent opinions. It is therefore the proper test to use in evaluating abortion statutes.

\section{B. The Casey Test Versus the Bellotti Test}

The Casey test is also the proper one to use when evaluating abortion-related statutes that specifically regulate minors. Although the Casey Court used the "undue burden" test to evaluate all of the provisions of the Pennsylvania statute, including those affecting only minors, ${ }^{127}$ lower federal courts often evaluate such laws by looking to Bellotti v. Baird.$^{128}$ However, because the Bellotti opinion is narrowly focused on judicial bypass requirements of a parental consent statute,

123. Janklow, 517 U.S. at 1175 (Stevens, J., mem. respecting denial of certiorari) (quoting Dorf, supra note 101, at 236). But see id. at 1178 (Scalia, J., joined by Rehquist, C.J., and Thomas, J., dissenting from the denial of certiorari and arguing that Salerno represents "a long established principle of our jurisprudence").

Professor Michael Dorf argues that the Salerno test is a bad one because all persons have the right to be judged by a valid rule of law, a right that would be infringed by the use of Salerno to evaluate a law's constitutionality. See Dorf, supra note 101, at 242-51. Moreover, Professor Dorf maintains that the test is not an accurate reflection of Supreme Court jurisprudence, since the "overbreadth" doctrine has been applied in several contexts outside of the First Amendment area, including cases involving the right to an abortion. See id. at 272.

124. City of Chicago v. Morales, 119 S. Ct. 1849, 1858 n.22 (1999).

125. See Burdick, supra note 95, at 875 .

126. See supra note 44 and accompanying text.

127. See Planned Parenthood v. Casey, 505 U.S. 833, 899-900 (1992) (joint opinion of O'Connor, Kennedy, and Souter, JJ.) (evaluating a parental consent requirement using the "undue burden" standard).

128. 443 U.S. 622 (1979) (plurality). For a brief discussion of lower federal courts use of the Bellotti test, see supra notes 36-37 and accompanying text. 
it provides a concrete framework of analysis only for that particular type of statute, not a useful general test for other types of regulations.

In analyzing a regulation affecting only minors, one should begin by looking to Casey, using Bellotti only as a supplement if the specific statute in question is one that can be evaluated using the Bellotti standard. That Bellotti should be used in conjunction with Casey is clear from the language of the Bellotti opinion itself. Justice Powell's plurality opinion in Bellotti not only presaged the general upholding of abortion regulation by the states but also relied on the same "undue burden" standard later employed and made famous by Casey: Justice Powell states that a minor's "constitutional right to seek an abortion may not be unduly burdened by state-imposed conditions ...."129 However, if state regulations do not amount to an undue burden, then, like a consent statute with an appropriate judicial bypass procedure, they are not an impermissible infringement on the minor's right to choose abortion. ${ }^{130}$

While making clear that the statute at issue was an undue burden, Bellotti does not suggest what other types of statutes and regulations could also be considered an undue burden. ${ }^{131}$ Thus, Bellotti is useful after Casey merely as a specific application of it. To determine whether a regulation is an undue burden on a minor's right to choose abortion, one should therefore use the Casey explanation of the "undue burden" standard.

\section{THE UnCONSTITUTIONALITY OF POTENTIAL LIABILITY}

Because of several recent lawsuits similar to Jackson ex rel. Robinson v. A Woman's Choice, Inc., ${ }^{132}$ abortion providers have good reason to be concerned about stumbling unwittingly into civil or criminal liability. ${ }^{133}$ Perhaps because the focus of the recent litigation

\footnotetext{
129. Bellotti, 443 U.S. at 648 (emphasis added).

130. See id. at 647.

131. Simply put, Justice Powell defines certain types of statutes as an undue burden per se. That is, a minor's right to obtain an abortion is unduly burdened by a parental consent requirement if the requirement does not contain a judicial bypass option that will allow a mature minor to make the abortion decision herself, and an immature minor to obtain an abortion that is in her best interest. See id. However, Bellotti does not indicate what other types of statutes and regulations would also be an undue burden. Thus, to determine whether a regulation is an undue burden on a minor's right to choose abortion, one should use the Casey explanation of the "undue burden" standard, keeping in mind that after Bellotti a state may be able to justify regulations by its interest in protecting immature decisionmakers from themselves.

132. 503 S.E.2d 422 (N.C. Ct. App. 1998).

133. In addition to Jackson, other recent litigants have attempted to make abortion provid-
} 
has been on abortion providers rather than on abortion patients, not enough attention is paid to the ultimate effect such liability will have on minor patients. By deterring many or most providers from performing abortions on minors, such liability has the potential to eliminate, or to burden severely, the ability of minors to obtain abortions.

Once Casey is accepted as the proper test, it is easy to see that laws establishing this kind of potential criminal liability of abortion providers should be invalidated. The reasons for finding such statutes unconstitutional are the same as those given by courts that have invalidated "partial-birth" abortion statutes. Abortion providers in both cases will be fearful of portentous liability they cannot control, and hence less willing to provide abortions. ${ }^{134}$ Arguably, the threat of liability is an unconstitutional undue burden on the right of minors to obtain elective abortions because of the chilling effect such liability will have on abortion providers.

\section{A. One Application of Casey: The "Partial-Birth" Abortion Cases}

Accepting Casey as the proper test, it is not difficult to conclude that a law having a chilling effect on abortion providers is unconstitutional, since a law that effectively eliminates abortion providers would be the most "substantial obstacle" possible for a woman seeking an abortion. Indeed, nearly all courts that have considered the question have held that a law serving to dissuade abortion providers from performing abortions is unconstitutional under the "undue burden" test described in Casey. ${ }^{135}$ The recent decisions holding "partialbirth" abortion statutes to be unconstitutional are the best example.

ers liable despite their good-faith efforts to comply with the law. See, e.g., Boykin v. Magnolia Bay, Inc., 570 So. 2d 639, 641-42 (Ala. 1990) (ruling that the minor was in pari delicto because she had lied about her age to the abortion clinic, and was thus not permitted to recover damages); see also Planned Parenthood, Sioux Falls Clinic v. Miller, 63 F.3d 1452, 1467 (8th Cir. 1995) (reasoning that the threat of civil liability "is more than enough to chill the willingness of physicians to perform abortions in South Dakota"); Okpalobi v. Foster, 981 F. Supp. 977, 986 (E.D. La. 1998), aff'd 190 F.3d 337 (5th Cir. 1999) (finding the same unconstitutional chilling effect from a Louisiana statute); supra notes 87-88 (discussing the potential criminal liability of abortion providers under a New Mexico criminal statute).

134. See infra Part III.B.

135. See, e.g., Colautti v. Franklin, 439 U.S. 379, 396 (1979) (holding that statutes creating uncertainty as to what actions of an abortion provider might create liability are unconstitutional because of their "profound chilling effect on the willingness of physicians to perform abortions"). The question has come up more recently in the "partial-birth" abortion context and with statutes that create strict liability for abortion providers. See infra notes 141, 159 and accompanying text. 
A number of jurisdictions have recently passed statutes purporting to ban a procedure popularly dubbed "partial-birth abortion." However, exactly what procedures are being outlawed under these statutes is decidedly unclear. As one district court judge noted, "The term 'partial-birth abortion' is a term coined by legislators, antiabortion activists, and the media. It has no accepted medical meaning." ${ }^{136}$ The states that have passed "partial-birth" abortion statutes have argued that the laws merely ban a procedure known as a D \& X, a rarely performed procedure in which "the physician may grasp the fetus by the feet or legs and draw the fetus intact through the cervix into the vagina where the fetal head may get stuck." 137 If this occurs, "the physician [may] . . . collapse the fetal head in order that the fetus may be delivered intact." ${ }^{138}$ However, a typical statute says nothing about the D \& X procedure, but bans all "abortion[s] in which the person performing the abortion partially vaginally delivers a living human fetus before killing the fetus and completing the delivery." ${ }^{139}$ This language is broad enough to include all of the most common abortion procedures. ${ }^{140}$

All of the district courts that have considered the constitutionality of "partial-birth" abortion statutes have found them likely to be unconstitutionally vague, as well as an unconstitutional infringement on a woman's right to abortion under the Casey "undue burden" test. ${ }^{141}$ To date, only one circuit court has decided a "partial-birth"

136. Richmond Med. Ctr. for Women v. Gilmore, 11 F. Supp. 2d 795, 799 (E.D. Va.), rev'd, 144 F.3d 326 (4th Cir. 1998) (Luttig, J., granting stay).

137. Planned Parenthood v. Verniero, 41 F. Supp. 2d 478, 484 (D.N.J. 1998).

138. Id.

139. N.J. Stat. Ann. § 2A:65A-6(e) (West Supp. 1999) (enjoined by Verniero, 41 F. Supp. $2 \mathrm{~d}$ at 504-05).

140. See Verniero, 41 F. Supp. 2d at 491 (noting, for example, that the phrase "partially vaginally delivers" could reasonably be interpreted to include any abortion in which a fetal part is delivered into the vagina, a phenomenon that has the potential to occur in nearly every abortion procedure).

141. See Causeway Med. Suite v. Foster, 43 F. Supp. 2d 604, 612-13, 615-19 (E.D. La. 1999); Verniero, 41 F. Supp. 2d at 504; Carhart v. Stenberg, 11 F. Supp. 2d 1099, 1131-32 (D. Neb. 1998); Gilmore, 11 F. Supp. 2d at 819, 825; Planned Parenthood v. Miller, 1 F. Supp. 2d 958, 962-64 (S.D. Iowa 1998); Hope Clinic v. Ryan, 995 F. Supp. 847, 853-60 (N.D. Ill. 1998); A Choice for Women v. Butterworth, No. 98-0774, 1998 WL 1070946, at *5-*10 (S.D. Fla. Dec. 2, 1998); Planned Parenthood v. Woods, 982 F. Supp. 1369, 1376-79 (D. Ariz. 1997); Evans v. Kelley, 977 F. Supp. 1283, 1304-11, 1315-18 (E.D. Mich. 1997); see also Little Rock Family Planning Servs., P.A. v. Jegley, No. 97-581, 1998 U.S. Dist. Lexis 22325, at *86 (E.D. Ark. Nov. 13, 1998) (finding a "partial-birth" abortion statute unconstitutional for three reasons: "it is unacceptably vague, it imposes an undue burden on women seeking abortions, and it does not adequately protect the health and lives of pregnant women"). 
abortion case, agreeing with the district courts. ${ }^{142}$ Thus, the federal courts overwhelmingly agree that "partial-birth" abortion statutes are unconstitutional. ${ }^{14}$

A recent district court decision, Planned Parenthood $v$. Verniero, ${ }^{144}$ provides an example of the reasoning employed by the many courts that have found "partial-birth" abortion statutes to be unconstitutional. The opinion outlines the various types of abortion procedures commonly performed by abortion providers in order to demonstrate why the language of the statutes might be read to ban many or most types of abortion procedures. ${ }^{145}$ The Verniero court notes also that it has received a number of affidavits from abortion providers who state that the threat of liability would force them to stop providing abortions if the "partial-birth" abortion statute were to become effective. ${ }^{146}$ The court ultimately enjoins the statute on two related grounds: first, it finds the statute to be unconstitutionally vague; and second, it finds the vagueness of the statute creates an undue burden because of its potential chilling effect on abortion providers. $^{147}$

The court finds several provisions of the Act to be vague. First, "those subject to the penalties of the Act cannot, with any certainty, determine what conduct is prohibited." ${ }^{, 148}$ This renders the Act unconstitutional, because the "lack of precision ... leaves the Act open to arbitrary and discriminatory enforcement." ${ }^{, 149}$ Moreover, the court links this vagueness holding to its later determination that the statute

142. See Doyle, 162 F.3d at 471 (reversing the district court and ordering it to enter a preliminary injunction enjoining Wisconsin's "partial-birth" abortion statute). But see Richmond Med. Ctr. for Women v. Gilmore, 144 F.3d 326, 332 (4th Cir. 1998) (Luttig, J., granting stay) (disagreeing with the district court's decision to grant an injunction and staying that injunction on the grounds that the plaintiffs did not have standing because they did not perform the procedure banned under the "partial-birth" abortion statute and thus lacked a reasonable fear of prosecution), motion to vacate denied, 183 F.3d 303 (4th Cir. 1998).

143. The only currently valid opinion that did not hold a "partial-birth" statute to be unconstitutional on its face is Gilmore, 144 F.3d at 332. Even this opinion avoids the question of whether deterring abortion providers would be unconstitutional because it determines that the plaintiff physicians did not have standing to bring suit. See id. at 328.

144. 41 F. Supp. 2d 478 (D.N.J. 1998).

145. See id. at 483-85. The court eventually concludes that the statute's imprecise language may render illegal almost all of the most common and safest abortion procedures. See id. at 493.

146. See id. at 487.

147. See id. at 504.

148. Id. at 493.

149. Id. at 494 . 
represents an undue burden by emphasizing that "[a] higher degree of clarity is required when 'uncertainty induced by the statute threatens to inhibit the exercise of constitutionally protected rights." 150

In determining that the Act is likewise an undue burden under Casey, the court reemphasizes that the statute's vague, imprecise language could reasonably be interpreted as a ban on most conventional abortion procedures. ${ }^{151}$ The possibility that the statute might be interpreted in this way would create uncertainty for abortion providers as to whether they must stop performing these conventional abortions in order to avoid liability. ${ }^{152}$ Because the statute would engender such uncertainty regarding potential liability, the court concludes it would "chill[] physicians from performing most conventional abortion procedures ... thereby impos[ing] an undue burden on a woman's constitutional right to terminate a pregnancy." ${ }^{153}$

Other district courts have used similar reasoning in finding that, even if "partial-birth" abortion statutes do not actually forbid certain procedures, the belief that they might do so will have an unconstitutional chilling effect. ${ }^{154}$ As one court explains, "If the plaintiffs chose to stop offering the D \& E procedure to their patients, it would impose an undue burden on the patients' right to seek an abortion because it would deprive them of the most common and safest method of abortion procedure in the second trimester."155

\section{B. The Unconstitutional Chilling Effect of Potential Liability}

Like the "partial-birth" abortion statutes, the recent efforts to impose liability on abortion providers for failing to ensure that their minor patients have actually obtained parental consent are unconstitutional under the Casey "undue burden" test. Statutory provisions

150. Id. at 490 (quoting Colautti v. Franklin, 439 U.S. 379, 391 (1979)).

151. The court had earlier determined that one possible interpretation of the statute was that it banned all abortion procedures except hysterotomies and hysterectomies. See id. at 499; supra notes 139-40, 145-46.

152. See Verniero, 41 F. Supp. 2d at 490.

153. Id. at $499-500$.

154. See, e.g., Richmond Med. Ctr. For Women v. Gilmore, 11 F. Supp. 2d 795, 825 (E.D. Va.) (noting that, under the statute, doctors "would have to choose between a cessation of performing [conventional abortions] or potential prosecution under the Act"), rev'd on other grounds, 144 F.3d 326 (4th Cir. 1998) (Luttig, J., granting stay); Planned Parenthood v. Woods, 982 F. Supp. 1369, 1377-78 (D. Ariz. 1997) (explaining that, if the statute were to go into effect, "physicians would fear prosecution and civil liability when performing any [conventional abortion]," with the likely result that such procedures would no longer be available).

155. Gilmore, 11 F. Supp. 2d at 825. 
that could be construed as creating strict liability have already been held to be "likely" ${ }^{156}$ unconstitutional in several jurisdictions. ${ }^{157} \mathrm{Al}-$ though no case has yet been brought respecting a statute with a negligence standard, such statutes should be held unconstitutional as well. ${ }^{158}$

1. Strict liability. Statutes imposing strict liability on abortion providers would create a deterrent nearly identical to the one found unconstitutional by the courts that have decided the "partial-birth" abortion cases. Indeed, most of the courts that have considered the constitutionality of such statutes have agreed that strict liability would chill the willingness of abortion providers to perform abortions, an effect which renders the statutes unconstitutional. ${ }^{159}$

Strict liability is likely to have this effect because abortion providers facing such liability can never be sure that they are shielded from liability until they cease performing abortions on minors. Just as the recent "partial-birth" abortion statutes create uncertainty as to whether certain types of common procedures are illegal, abortion providers will never be certain whether they have incurred liability under a strict liability statute, since abortion providers could be held liable for unconscious or unwitting violations of the law. ${ }^{160}$ Abortion providers would therefore be unable to protect themselves from many different types of situations-for example, a minor who has exceptionally convincing fake identification, or who brings with her someone posing as a parent. In fact, abortion providers will only be able to avoid liability by refusing to perform abortions on all prospective patients who appear as if they could be under eighteen. ${ }^{161}$

156. Courts construing statutes will find them likely unconstitutional because they are following a canon of statutory construction that forces courts to interpret statutes so as to avoid potential (or likely) constitutional problems. See, e.g., Jackson ex rel. Robinson v. A Woman's Choice, Inc., 503 S.E.2d 422, 425-26 (N.C. Ct. App. 1998).

157. See infra note 159 and accompanying text.

158. This is so at least to the extent that such a statute does not contain an exemption for an abortion provider who has obtained an apparently valid consent form from the minor before the abortion is performed. See infra note 180 and accompanying text.

159. See, e.g., Planned Parenthood, Sioux Falls Clinic v. Miller, 63 F.3d 1452, 1467 (8th Cir. 1995); Okpalobi v. Foster, 981 F. Supp. 977, 986 (E.D. La. 1998), aff'd 190 F.3d 337 (5th Cir. 1999); Jackson, 503 S.E.2d at 425.

160. For example, if the North Carolina statute were interpreted as a strict liability statute, Jackson's doctor would have been held liable for having performed the abortion despite having attempted to comply with all the legal requirements.

161. This might mean that women much older than 18 would be turned away, since abortion providers might be fearful of misidentifying an especially mature-looking minor as an 
This potential unwillingness on the part of abortion providers is the most "undue" of any burden a woman seeking an abortion might face. An inability to find a doctor willing to perform an abortion will be not only a "substantial" obstacle, but an unconquerable one. And statutes that evoke uncertainty as to what acts performed by an abortion provider might generate liability are acknowledged by courts to "have a profound chilling effect on the willingness of physicians to perform abortions ....",162

Moreover, a response other than an outright refusal to perform abortions on minors may also create an undue burden. Any abortion provider who is willing to continue performing abortions on minors in the face of a strict liability statute might decide to safeguard herself against liability by implementing procedures designed to eliminate as much fraud as possible. For example, an abortion provider could implement a policy of performing abortions only when the parent's signature has been notarized, or when the parent actually accompanies the minor and signs the permission slip in the doctor's presence. These types of restrictions, however, might protect physicians at the expense of many of their minor patients. Such restrictions could themselves work an undue burden on the class for whom they are relevant.

A notarization requirement, for example, implicates privacy interests. A parent might be willing to consent to the abortion, but unwilling to share the fact of the abortion or his consent to the abortion with a notary. Further, rural teenagers might have more difficulty in convincing a parent to consent when that consent also entails a long drive to a notary's office.

Convincing a parent to accompany his minor daughter to the abortion clinic might prove no easier for the minor. One can easily imagine that minors who have the most attenuated relationships with their parents-and the hardest time getting parental consent in the first place-might find it difficult or impossible to convince a consenting parent to take the time to come with them to an abortion clinic. ${ }^{163}$ This would be a particular problem for teenagers in rural areas who live far away from a clinic. ${ }^{164}$ Thus, responses to strict liability

\footnotetext{
adult.

162. Colautti v. Franklin, 439 U.S. 379, 396 (1979).

163. In some cases, there might also be financial implications. A parent in a poor family, for instance, might be unable to afford both the cost of the abortion and the time spent away from work.

164. In fact, finding and getting to an abortion provider is often difficult enough in itself.
} 
that are less restrictive than a complete refusal to provide abortions to minors might also create substantial obstacles for minors.

2. Negligence. Whether standards of culpability other than strict liability might also be unconstitutional has not yet been considered by the courts. Most of the statutes applying liability do not state any mens rea requirement, and many have been either struck down as unconstitutional because of the potential for strict liability ${ }^{165}$ or interpreted as not imposing strict liability because of the probable unconstitutionality of such a construction. ${ }^{166}$

However, a statute that explicitly imposes a negligence standard of liability might have the same chilling effect as a strict liability statute, since the lack of a knowledge or intent requirement means abortion providers would still face liability for unconscious or unwitting violations of the law. A statutorily imposed duty that a physician exercise "reasonable" care in policing his minor patients does not give much more certainty than strict liability-it merely creates a different type of uncertainty.

Indeed, the Supreme Court recognized in New York Times $v$. Sullivan ${ }^{167}$ that a negligence standard, as well as a strict liability standard, can have an unconstitutional chilling effect. ${ }^{168}$ In Sullivan, the Court held that libel prosecutions require proof of "'actual malice'that is ... knowledge that [a libelous statement] was false or [made] with reckless disregard of whether [it] was false or not." 169 A state's failure to grant immunity for any standard less than actual malice (including a negligence or strict liability standard) creates an impermis-

Eighty-four percent of counties in the United States do not have abortion providers. See THE NARAL Foundation, Who Decides: A State-By-State Review of Abortion and ReProductive Rights vii (7th ed. 1998) (citing Stanley K. Henshaw \& Jennifer Van Vort, Abortion Services in the United States, 1991 and 1992, FAM. Plan. PersP., May/June 1994, at $100,103)$. Many women in rural areas are forced to drive hundreds of miles to access an abortion provider. See id. at iv. Moreover, the number of physicians who provide abortions to patients is shrinking nationwide; both North Dakota and South Dakota have only one abortion provider each. See id. at vii.

165. See Planned Parenthood, Sioux Falls Clinic v. Miller, 63 F.3d 1452, 1467 (8th Cir. 1995); Okpalobi v. Foster, 981 F. Supp. 977, 986 (E.D. La. 1998), aff'd 190 F.3d 337 (5th Cir. 1999).

166. See Jackson ex rel. Robinson v. A Woman's Choice, Inc., 503 S.E.2d 422, 426 (N.C. Ct. App. 1998) (holding that the statute does not impose strict liability, but failing to make clear exactly to what standard the statute does hold abortion providers).

167. 376 U.S. 254 (1964).

168. See id. at 279-80.

169. Id. at 280. 
sible "threat of damage suits ... [ [that would] 'dampen the ardor of all but the most resolute, or the most irresponsible ...." ${ }^{170}$ A higher standard than negligence is thus required to protect the fundamental right to speak precisely because a lower standard than actual malice is presumed to chill speech.

Of course, it is true that First Amendment and abortion rights are not exactly parallel. The constitutionality of speech regulations is subjected to a form of scrutiny that may be considered stricter than the "undue burden" test. Therefore, a standard less exacting than "actual malice" might be required for abortion-provider liability to be constitutional. Possibly, recklessness, or even gross negligence, would suffice. However, given that both speech and abortion are fundamental rights, a good argument for "actual malice" could be made, even though I do not attempt it here. ${ }^{171}$ Certainly, however, the much lower standard of negligence would have a chilling effect in the abortion context. First, any credible threat of a lawsuit might be enough to convince a physician to eliminate only one part of his practice by ceasing to provide abortion services to minors. ${ }^{172}$ Moreover, the uncertain outcome of these potential lawsuits would further "dampen the ardor of all but the most resolute, or the most irresponsible" abortion providers.

Like the abortion providers in New Jersey who would have stopped providing all abortions that might have been covered by the "partial-birth" abortion ban, ${ }^{173}$ abortion providers practicing in states with statutes demanding that doctors police their minor patients-but not giving strict guidelines for what they must do to avoid liabilitycan never know exactly what actions a jury might deem negligent. Juries hearing the same factual situations might-and are legally allowed to-rule based on a "reasonableness" standard that might le-

170. Id. at 282 (quoting Barr v. Matteo, 360 U.S. 564, 571 (1959)).

171. I argue only that at least the threat of liability for negligence, if not recklessness, creates too much of a deterrent to satisfy the Casey test.

172. Indeed, extra paperwork appears to have been enough to deter many physicians from continuing their abortion practice. In the 10 -year period immediately preceding the Casey decision-in which abortion regulations became more prevalent as the Supreme Court began to show signs it might overrule Roe-the number of abortion providers dropped $18 \%$. See THE NARAL FOUNDATION, supra note 164, at vii. In the four years following Casey, which opened the floodgates for state abortion regulations, the number of physicians dropping abortion from their practice increased dramatically, rising to 85 dropouts per year compared to 51 per year in the four years prior to Casey, a more than $50 \%$ increase in the number of dropouts. See Stanley K. Henshaw, Abortion Incidence and Services in the United States, 1995-1996, FAM. Plan. PERSP., Nov./Dec. 1998, at 263, 267-68.

173. See Planned Parenthood v. Verniero, 41 F. Supp. 2d 478, 499 (D.N.J. 1998). 
gitimately mean different things to different people, and judges do not have the ability to overturn jury decisions if the jury's findings were within reason. ${ }^{174}$ Moreover, because of the strong beliefs many people have about the immorality of abortion, as well as the great prejudice that may accompany such beliefs, abortion providers would certainly be rightly concerned with how even their good-faith efforts might be judged by members of their communities. ${ }^{17}$

Unlike the malpractice liability doctors face for failure to obtain informed consent from their patients-standards that have been litigated extensively-doctors facing liability for failure to exercise care in assuring that a valid parent's signature has been obtained cannot know exactly to what standard they will be held. No case law exists that might help answer this question, and no jury has ever decided such a case. ${ }^{176}$

In facing liability for his good-faith efforts to obey the law, $\mathrm{Mu}-$ keshia Jackson's abortion provider, Dr. Washington, could not have known-either from looking to the statute (which was silent on the question of what would be per se reasonable), or from prior decisions (since none existed) - whether he might be held liable for negligence. Though he thought that he had fully complied with all legal requirements, a judge interpreting a statute imposing liability for negligence might have ruled that a jury could properly view an abortion provider as reasonable only in the exercise of extra-vigilant measures to assure himself that the mother's signature was not a forgery. Indeed, a jury might have determined that a physician should assume fraud to be likely, in which case he would surely not have been acting reasonably

174. See, e.g., United States v. Watkins, 519 F.2d 294, 297 (D.C. Cir. 1975).

175. Widespread violence aimed at clinics and abortion providers demonstrates the malevolent attitude anti-choice citizens have towards doctors who choose to provide abortion services. In October 1998, Dr. Barnett Slepian was shot by a sniper while in his home. See David Van Biema, The Shattered Peace, TIME, Nov. 2, 1998, at 78, 78. In the past 15 years, abortion clinics have been subjected to violent attacks 167 times. See Maggie Haberman, Two Decades of Terror, N.Y. PosT, Oct. 26, 1998, at 18. Between 1993 and 1998, seven people were killed in clinics in the United States by protestors. See id. The violence against clinics and doctors has become such an enormous problem that many of the same states that have passed restrictive abortion regulations have also passed laws "to protect medical personnel ... against blockades and violence." THE NARAL FOUNDATION, supra note 164, at xi. Four state legislatures-California, Michigan, New Mexico, and Pennsylvania-have passed resolutions that condemn violence aimed at abortion clinics. See id.

176. Nor do doctors generally face liability for failing to obtain parental consent in other contexts, since the "mature minor" exception shields them from liability in cases where a mature minor lies about her age. See Cardwell v. Bechtol, 724 S.W.2d 739, 744-45 (Tenn. 1987); supra note 11. 
by doing nothing more than accepting an apparently valid note. On the other hand, for Dr. Washington to believe that a court would rule that the acceptance of an apparently valid note was per se reasonable is no less plausible. ${ }^{177}$ This type of uncertainty might well be as unacceptable to a physician as the uncertainty associated with strict liability statutes.

Even if not deterred outright by the vagueness inherent in a negligence standard, some physicians facing liability for negligence may try to overcompensate for the uncertainty by establishing exacting proof of a signature's validity. As discussed above, abortion providers who implement more vigilant requirements avoid liability by creating different, yet still substantial, obstacles for many of their patients. ${ }^{178}$ Thus, both because the need for certainty is essential where constitutional rights are involved, ${ }^{179}$ and because requiring a doctor to do more than accept a note might lead to other obstacles for many minors, a constitutional enforcement statute should allow defendants to assert, as a good-faith defense, that they received from the minor a permission slip with an apparently valid signature. ${ }^{180}$

\section{THE CONSEQUENT DIFFICULTIES OF ENFORCING PARENTAL CONSENT STATUTES}

The conclusion that abortion providers cannot be forced to police their minor patients raises one obvious question: how can fraud like that perpetrated by Mukeshia Jackson in North Carolina be prevented without enlisting abortion providers to help stop it? Parental consent statutes could theoretically cease to have any operative effect. ${ }^{181}$ However, even though parental consent statutes may lack

177. Taking action in "good faith" often statutorily exempts doctors from liability. See, e.g., Fla. STAT. ANN. § 893.05(1) (West 1999) (exempting from liability doctors who in "good faith" prescribe addictive drugs to addicts during the course of professional treatment); GA. CODE ANN. § 51-1-29 (Michie 1982) (exempting from liability doctors who give emergency care at an accident scene in "good faith").

178. See supra notes 163-64 and accompanying text.

179. See Colautti v. Franklin, 439 U.S. 379, 390-91 (1979).

180. For a model of a statute providing such a good-faith defense for abortion providers, see Baird v. Attorney Gen., 360 N.E.2d 288, 302 (Mass. 1977).

181. States might be able to reduce fraud by passing statutes requiring minors to have their parents' signatures notarized. Louisiana, for example, already requires this. See LA. REV. STAT. ANN. § 40:1299.35.5(A)(1) (West 1999). While such a requirement might not eliminate all fraud, it would serve to prevent most.

However, this is perhaps not a viable solution either, since a notarization requirement might itself be unconstitutional under Casey. Arguably, the class of minors who could obtain 
teeth without complementary statutes requiring abortion providers to be regulators, the latter statutes are still unconstitutional.

Normally, of course, regulations may lawfully require private citizens to police minors while providing services not permitted them. In such cases, even strict liability may be perfectly legitimate. For example, dram shop laws hold sellers of alcoholic beverages liable for selling to underage persons even if the dram shop owner might reasonably have believed the buyer was of age. ${ }^{182}$ Such laws may result in overenforcement of the drinking-age laws, such that even persons well over twenty-one years old may be unable to buy alcoholic beverages if they cannot show proof of age. While this is a perfectly legitimate result in most contexts, the same type of overenforcement has been deemed impermissible in areas involving fundamental rights.

For instance, although the government is permitted to pass laws regulating certain types of speech, the First Amendment prohibits otherwise permissible laws from taking effect when these laws might have a chilling effect on constitutionally protected speech. ${ }^{183}$ One example is a law that does not actually ban protected speech, but frightens people into believing that it does.

In NAACP v. Button, ${ }^{184}$ the Supreme Court struck down a Virginia statute that prohibited any arrangement in which prospective litigants were advised to seek legal assistance and given legal referrals. ${ }^{185}$ The Court made clear that its finding had nothing to do with whether the regulation fell under the state's police power: the Court found that Virginia had a valid interest in regulating certain traditionally illegal practices-specifically, barratry, ${ }^{186}$ maintenance, ${ }^{187}$ and

consent but not a notarized signature would, like the class of women burdened by the spousal notice requirement in Casey, face a "substantial obstacle" from a notarization requirement. The same problems would arise with a requirement that minors have a parent accompany them to the abortion clinic. See supra notes 162-64 and accompanying text.

182. All states have laws restricting the sale of alcohol to persons under 21 years of age. Many hold sellers strictly liable for selling to an underage person. See, e.g., ALA. CODE $§ 28-$ 3A-25(a)(3) (1998); Ky. REV. StAT. ANN. § 244.080 (Banks-Baldwin 1999); see also Swett v. Haig's, Inc., 663 A.2d 930, 931 (Vt. 1995) (holding that Vermont's Dram Shop Act imposes strict liability for injuries to third parties on dram shops that serve minors).

183. See, e.g., City of Houston v. Hill, 482 U.S. 451, $466-67$ (1987); Baggett v. Bullitt, 377 U.S. 360, 372 (1964); NAACP v. Button, 371 U.S. 415, 434-37 (1963).

184. 371 U.S. 415 (1963).

185. See id. at 444.

186. Barratry is defined as "[t]he offense of frequently exciting and stirring up quarrels and suits, either at law or otherwise." BLACK's LAW DICTIONARY 150 (6th ed. 1990).

187. Maintenance is defined as "[a]n officious intermeddling in a lawsuit by a non-party by maintaining, supporting or assisting either party, with money or otherwise, to prosecute or de- 
champerty ${ }^{188}$-but nonetheless held "that [the state's legitimate] interest $\mathrm{d}[\mathrm{id}]$ not justify the prohibition" imposed by the statute at issue. ${ }^{189}$

Laws like the one in Button are unconstitutional because "[t]he threat of sanctions may deter [the] exercise [of rights] almost as potently as the actual application of sanctions." exercise of a state's police power might still be unconstitutional because of its potential to impede the exercise of constitutionally protected rights.

Of course, First Amendment jurisprudence might be distinguished on the ground that the unconstitutional statutes directly impede the person holding the fundamental right. Such a distinction, however, is not as clear as it might seem. In Sullivan, for example, the speech that was threatened by the libel law was a paid advertisement, not an article authored by a Times writer. The New York Times might appropriately be viewed as a third-party "speech provider" analogous to the third-party abortion providers chilled by consent enforcement statutes.

Likewise, in Smith v. California, ${ }^{191}$ the First Amendment prompted the reversal of a third-party's conviction under a strict liability statute, even though that particular party's rights were not implicated. ${ }^{192}$ In Smith, a proprietor of a bookstore was convicted of possessing pornographic material under a statute that "included no element of scienter-knowledge by appellant of the contents of the book...."193 The Court found strict liability to be unacceptable where First Amendment rights were involved, finding that the public's First Amendment rights would in general be infringed by the statute. ${ }^{194}$ The infringement would occur because booksellers would naturally be cautious in the face of a strict liability statute and would

\footnotetext{
fend the litigation." Id. at 954 .

188. Champerty is defined as "[a] bargain between a stranger and a party to a lawsuit by which the stranger pursues the party's claim in consideration of receiving part of any judgment proceeds ...." Id. at 231.

189. Button, 371 U.S. at 439

190. Id. at 433; see also New York Times v. Sullivan, 376 U.S. 254, 279-80 (1964) (holding that a public official bringing a libel action against critics of his official conduct must prove "actual malice," as any lesser standard of culpability might dampen free expression).

191. 361 U.S. 147 (1959).

192. See id. at 155 .

193. Id. at 149.

194. See id. at 152.
} 
"tend to restrict the books [they] sell[] ..." tution does not generally forbid states from imposing strict liability on third-party service providers, ${ }^{196}$ it specifically does forbid it when the threat of strict liability will impinge upon other persons' constitutional rights.

Moreover, the Supreme Court has explicitly found a statute to be unconstitutional precisely because of that statute's chilling effect on third-party abortion providers. ${ }^{197}$ In Colautti v. Franklin, ${ }^{198}$ the Supreme Court had to determine the constitutionality of a statute that "subject[ed] a physician who performs an abortion to potential criminal liability if he fails to utilize a statutorily prescribed technique when the fetus 'is viable' or when there is 'sufficient reason to believe that the fetus may be viable." 199 The Court reaffirmed that "the State's interest in the potential life of the fetus reaches the compelling point at the stage of viability." 200 Yet, the Supreme Court also stated that an otherwise valid statute-indeed one that was enacted to further a state interest acknowledged to be compelling-cannot be held constitutional "where the uncertainty induced by the statute threatens to inhibit the exercise of [otherwise] protected rights," in particular the right to an abortion. ${ }^{201}$ Thus, the Colautti Court explicitly brought the "chilling" standard of the First Amendment into the abortion context, stating that " $[\mathrm{t}]$ he prospect of ... disagreement [over a statute's meaning by abortion providers and other medical experts] ... could have a profound chilling effect on the willingness of physicians to perform abortions ...." ${ }^{202}$ This, the Court held, made what might otherwise have been a valid regulation unconstitutional. ${ }^{203}$

195. Id. at 153.

196. Indeed, the Smith Court notes that in the case of food distributors, strict liability statutes are permissible as a way of "making the distributors of food the strictest censors of their merchandise ...." Id. at 152.

197. See Colautti v. Franklin, 439 U.S. 379, 390-94 (1979). Moreover, other courts have pointed out that the abortion provider, too, has a constitutional right to pursue his profession, a right that is unconstitutionally chilled by potential liability. See, e.g., Okpalobi v. Foster, 981 F. Supp. 977, 986 (E.D. La. 1998), aff'd 190 F.3d 337 (5th Cir. 1999) ("The statute has the purpose and effect of infringing and chilling the exercise of constitutionally protected rights of abortion providers ...."); see also Meyer v. Nebraska, 262 U.S. 390, 399-400 (1923) (holding that the right to pursue one's livelihood is a constitutionally protected right).

198. 439 U.S. 379 (1979)

199. Id. at 381.

200. Id. at 386.

201. Id. at 391.

202. Id. at 396 (emphasis added).

203. See id. at 396-97. 
Therefore, the Supreme Court may hold that a state's police power extends to the regulation of certain activities and still later hold statutes regulating those activities impermissible. As discussed earlier, a chilling effect on the right of minors to abortion is particularly likely in the case of uncertain abortion-provider liability. Moreover, this chilling effect interferes directly with the exercise of a fundamental right because abortion providers are essential to a woman's ability to obtain an abortion. Thus, some laws regulating abortion providers - as well as many laws regulating minors-may be permissible only in theory. State legislatures must walk a fine line to ensure that regulation does not simultaneously serve as a means of preventing abortions from occurring. Legislatures that fail to take into account the chilling effect of regulation ignore the inherent implications of the Supreme Court's abortion jurisprudence. ${ }^{204}$ Indeed, had the Casey record revealed that abortion providers were being deterred from performing abortions on minors, the Court would surely have had to conclude that the statute was unconstitutional. The very definition the same Court gave for an undue burden is "a state regulation that has the purpose or effect of placing a substantial obstacle in the path of a woman seeking an abortion of a nonviable fetus." ${ }^{205}$ As discussed earlier, the effect of deterring abortion providers constitutes a severe obstacle.

That parental consent statutes may be rendered impotent by a state's inability to enlist abortion providers as enforcers is therefore not inconsistent with the Supreme Court's view that such statutes are a valid exercise of a state's regulatory authority. In Casey, the Supreme Court was simply not asked to consider the problems a state may face in trying to enforce parental consent statutes without the concurrent ability to compel abortion providers to help it do so.

Finally, one should not assume that consent laws will be ineffective without a mechanism that could force abortion providers to help police their patients. To begin with, not all teenagers who obtain abortions are committing the type of fraud perpetrated by Mukeshia

204. See Planned Parenthood v. Casey, 505 U.S. 833, 877 (1992) (joint opinion of O'Connor, Kennedy, and Souter, JJ.) (stating that "a statute which, while furthering... some... valid state interest, has the effect of placing a substantial obstacle in the path of a woman's choice cannot be considered a permissible means of serving its legitimate ends"); Colautti, 439 U.S. at 394 (noting that the statute in question was unconstitutional insofar as it "presents serious problems of notice, discriminatory application, and chilling effect on the exercise of constitutional rights").

205. Casey, 505 U.S. at 877 (emphasis added). 
Jackson. While it may be true that the minors who actually obtain parental consent are the same ones who would have done so without parental involvement statutes, ${ }^{206}$ such statutes probably cause some minors to involve parents who would not have otherwise been informed of the pregnancy. At the very least, an assumption that the laws have some, even if not full, effect seems warranted.

Other legal contexts make clear that laws are assumed to have effect even when no enforcement mechanisms are put in place. The Supreme Court acknowledged and validated this assumption in Bowers v. Hardwick. ${ }^{207}$ Justice Powell's concurring opinion in Bowers indicated that the Georgia sodomy law was only constitutional because the state did not enforce it. ${ }^{208}$ Some regulations thus may be permissible only to the extent that they have symbolic, but not actual, effect.

Moreover, many state practices also attest to the assumption that citizens will obey the law. For example, states do not police compliance with regulations forbidding close relatives to marry. States consider the disclosure of this type of law to marriage license applicants-along with a clerk asking the couple to state that they are not related in a way that would violate the law-to be enough of a deterrent. In such cases, people are presumed to be law-abiding and deterred from breaking the law by the knowledge of its existence.

Presumably, an approach similar to that noted above in the marriage license context would be effective in the consent law context. An abortion provider could disclose that parental consent is required and verify that the signature on the permission slip is a parent's, just as the clinic did in Jackson. Notably, the consequences of fraud are very similar in both the marriage license and consent contexts: in both, the state interest involves protection of potential life. The ad-

206. The minors who actually obtain parental approval may be the same minors who have a good-enough relationship with their parents that they would have gotten parental advice even without a law requiring it. In fact, studies conducted in states without parental involvement laws show that most parents who have knowledge of the pregnancy are told by the daughters themselves, and that the great majority supported their daughters' decisions to have abortions. See Stanley K. Henshaw \& Kathryn Kost, Parental Involvement in Minors' Abortion Decisions, FAM. Plan. PERSP., Sept./Oct. 1992, at 196, 196. Moreover, the actual effects of parental involvement laws on minors who would not have otherwise sought advice may be negative, since a third of all minors who decide not to tell a parent about their pregnancies and their decisions to have abortions say that their decisions are motivated by a fear of violence based on earlier experiences with parental violence. See id.

207. 478 U.S. 186 (1986).

208. See id. at 197-98 (Powell, J., concurring) (opining that any punishment imposed on someone for violation of a sodomy statute would be unconstitutional under the Eighth Amendment). 
verse result of fraud might be the conception of a fetus with genetic defects in the case of a closely related married couple, or an aborted fetus in the case of a minor who fails to involve her parents in the abortion decision.

Consent statutes would not be completely inoperative in the absence of abortion-provider liability. But even if they were, the fact that the Casey Court found a state interest in certain abortion regulations does not mean that states have a right to press those interests at the expense of constitutionally protected rights.

\section{CONCLUSION}

By allowing states to legislate in the abortion arena, the Casey Court has opened a back door through which the states can effectively restrict the exercise of constitutional rights. Since the Casey decision, the number of abortion providers has dropped at a rapid rate. ${ }^{209}$ In the four-year period subsequent to Casey, the number of physicians dropping abortion from their practices increased by more than fifty percent compared to the four-year period preceding the decision. ${ }^{210}$ This dramatic decline illustrates the way in which statutes designed to promote informed decisionmaking may actually be working to wrest decisions away from those who are constitutionally entitled to make them.

Unfortunately, the actual effects of the statutes are not obvious, precisely because they are indirect. The insidious legislation involved is effective precisely because each individual provision appears innocuous. Perhaps only the combined effect of regulations that appear to impose strict liability, steadily increasing required paperwork, and notification duties finally makes a previously dedicated doctor drop abortion from his practice. These regulations are the "new battlefield" 211 for rights activists, a battlefield on which the attack does not appear at first glance to be directed at the minors and adult women whose rights are ultimately threatened. Yet, it is women-all women-who are put at risk by these statutes. In upholding the right of women to choose abortion, the Casey Court acknowledged that "[t]he ability of women to participate equally in the economic and social life of the Nation has been facilitated by their ability to control

209. See supra note 164 .

210. See supra note 172.

211. Okpalobi v. Foster, 981 F. Supp. 977, 986 (E.D. La. 1998), aff'd 190 F.3d 337 (5th Cir. 1999). 
their reproductive lives." ${ }^{212}$ Taken together, the post-Casey regulations threaten this ability and thus should be invalidated. As one district court judge has observed, "Such backhanded and subtle attempts that chip away at a vital component of a person's liberty will not be tolerated." ${ }^{213}$

212. Planned Parenthood v. Casey, 505 U.S. 833, 856 (1992) (joint opinion of O'Connor, Kennedy, and Souter, JJ.).

213. Okpalobi, 981 F. Supp. at 986. 